\title{
Vass Kitti*
}

\section{Külön út - külön siker}

Tanulmányomban az Európai Unió egyik tagállamát, a korporatív ${ }^{1}$ gazdaság egyik példájának tekinthető Ausztria ${ }^{2}$ kis, nyitott, föderális berendezkedésü államát veszem górcső alá.

Az osztrák gazdaságban a második világháború utáni újjáépitési periódust viharos gazdasági expanzió jellemezte; az olajválságot követően pedig a fejlett tőkés országok között egyedülálló módon alacsony infláció és alacsony munkanélküliség, valamint az átlagosnál dinamikusabb gazdasági növekedés állította az országot a figyelem köpontjába. A felfokozott külső gazdaságpolitikai érdeklödés miatt ekkor került széles körü vizsgálat alá az osztrák modell, azaz az osztrák gazdaságpolitika és az intézményrendszer. Az 1980-as évek elején azonban a gazdaságban strukturális problémák jelentkeztek, melynek eredményeként a növekedési ütem jelentös mértékben lelassult, míg a 2000-ben bekövetkező politikai változások végre ismét kedvezö gazdaságpolitikai fordulatot hoztak.

Az alábbiakban elsőként a második világháború utáni újjáépités során kialakult gazdasági helyzetet mutatom be, majd az osztrák társadalmi partnerség kialakulását, változásait és szerepét vizsgálom. Ezt követően napjaink Ausztriáját elemzem a fenntarthatóan kiegyensúlyozott államháztartás szempontjából, fókuszálva az államháztartás helyzetére és a szövetségi berendezkedésböl adódó komplex fiskális kapcsolatokra.

Journal of Economic Literature (JEL): H62, H63

Kulcsszavak: deficit, adósság, adósságkezelés

\footnotetext{
* A szerző a Debreceni Egyetem Közgazdaságtudományi Karának doktorandusza. E-mail: vass.kitti@chello.hu. Köszönettel tartozom Csaba Lászlónak értékes észrevételeiért.

${ }^{1}$ A kapitalista gazdaság két történeti típusa - a szabadversenyes piacgazdaság, illetve az állami beavatkozással összekapscsolódó vegyesgazdaság - között foglal el köztes helyet a tárgyalásos (neokorporatív) gazdaság. Jellemzője, hogy az állam nem autonóm szereplö, hanem a magángazdaság érdekcsoportjainak befolyása alatt áll, a gazdaság koordinációja pedig a kulcsfontosságú gazdasági szereplök érdekszervezetei között létrejött alkuk révén valósul meg. A sikeres döntéshozatal előfeltétele a kevés számú kompetens, megbízható szereplő részvétele az alkufolyamatokban, melyek az egyes érdekcsoportok, állami bürokrácia és a politikai pártok között folynak. A neokorporatív rendszer fénykora az 1950-es és az 1980-as évek közé tehető, napjainkra pedig jelentős változásokon ment keresztül. A decentralizációs hullám, a világgazdasági változások következtében a makroszintủ érdekegyeztetést felváltotta az alacsonyabb, mezo-, illetve mikroszintủ egyeztetési rendszer (Gedeon 2000).

${ }^{2}$ Az Osztrák Szövetségi Köztársaság kilenc tartományból áll, melyeket 84 körzetre tagoltak, majd pedig további közösségekre osztottak fel.
} 


\section{A dinamikus példaország időszaka}

Az 1945. április 29-én megalakult második Osztrák Köztársaságnak szembesülnie kellett a második világháború következményeivel: megsemmisült a nemzeti vagyon számottevő része, élelmiszerhiány és vágtató infláció lépett fel, virágzott a feketepiac, valamint bevezették a jegyrendszert. Az újjáépítési periódust hátráltatta az ország megszállási övezetekre való felosztása, ${ }^{3}$ hiszen a nemzetközi helyzet rendezetlensége miatt nehezen indultak meg a beruházások. ${ }^{4}$

Az osztrák gazdaságnak az ötvenes évek elejéig tartó helyreállítási periódusában az ipari szektor rekonstrukciója és fejlesztése gyorsabb ütemben történt, mint a mezőgazdasági szektoré, mivel a nemzetközi segélyek ${ }^{5}$ - melynek következtében nem volt tőkehiány - azt támogatták jobban. A nyugati tartományok iparosítása révén az ipari létesítmények a korábbinál arányosabban oszlottak el az ország területén, bár a Bécsi-medence továbbra is a legnagyobb ipari övezet maradt. Megjegyzendő, hogy 1946 és 1947 között Ausztriában is jelentős államosítási hullám söpört végig. ${ }^{6}$

A második köztársaság újjáépülő gazdaságának talán legsajátosabb vonása volt, hogy a világháború utáni időszakban - a hasonló helyzetű országoktól eltérően - nem beszélhetünk tömeges munkanélküliségről. Az 1952-1953-as stabilizációs válság - melyet restrikciós intézkedéssorozattal fékeztek meg, és amelynek keretében megvalósult a deficit mértékének csökkentése adóemelésen és kiadáscsökkentésen keresztül - és az időszakos ingadozások kivételével fokozatosan megvalósult a teljes foglalkoztatottság. Sőt később, a hatvanas években a növekvő gazdaság igényeit már külföldi vendégmunkásokkal (török, jugoszláv) kellett fedezni. ${ }^{7}$ A munkaerő-piaci helyzet csak a nyolcvanas évek felé vett kedvezőtlen fordulatot.

Az újjáépítési periódust viharos gazdasági expanzió jellemezte, az ezt kísérő inflációt pedig az 1951-52-ben végrehajtott stabilizációs intézkedések fékezték meg véglegesen. A stabilizációval egy időben lezárult a Marshall-segély folyósítása, ezután az ország már csak a saját erejére támaszkodhatott. A korabeli sajtó által osztrák csodának nevezett jelenség 1953-ban kezdődött és 1954-ben bontakozott ki. Az átmeneti 1967-68-as recessziót követő újabb fellendülés végét az 1973-as energiaár-robbanás jelentette, ami egyben így egy hosszú fejlődési szakasz vége is volt.

Az olajválság után a fejlett tőkés országok között egyedülálló módon az alacsony infláció és az - immár jellemző sajátosságnak nevezhető - alacsony munkanélküliség, valamint az átlagosnál dinamikusabb gazdasági növekedés állította a figyelem központjába az osztrák gazdaságot. Az érdeklődés miatt ekkor került széles körü vizsgálat alá az osztrák modell, azaz az osztrák gazdaságpolitika és az intézményrendszer.

Az osztrák gazdaság teljesítményét az 1971 és 2004 közötti periódusban az 1. sz. ábra mutatja be, míg a munkaerö-piaci helyzet 1960 és 2004 közötti alakulását a 2. sz. ábra szemlélteti. A 3. sz. ábra pedig az árszínvonal alakulását bemutató GDP-deflátor ${ }^{8} 1971$ és 2004 közötti alakulását ábrázolja.

\footnotetext{
3 Tirol és Voralberg francia, Stájerország és Karintia angol, Salzburg és Felső-Ausztria Dunától délre eső területe amerikai, Felső-Ausztria északi része és Alsó-Ausztria és Burgenland szovjet megszállási övezet volt. Bécset szintén négy övezetre osztották fel, a belvárost a négy győztes hatalom közösen irányította.

${ }^{4}$ Az egyenlőtlen regionális fejlődésnek részben következménye, részben kiváltója, hogy a fiatal mobil szakképzett munkaerő egy része átvándorolt a nyugati területekre.

${ }^{5}$ Meghatározó szerepe volt az 1952-ig nyújtott Marshall-segélynek.

6 1946-ban született törvény a kulcsfontosságú ipari ágazatok és a nagybankok államosításáról.

Ausztriában foglalkoztatott külföldiek számát csak 1974-től kezdték el fokozatosan csökkenteni.

${ }^{8}$ A GDP-deflátort a folyó áras (adott évi árakon) GDP és a változatlan áras reál-GDP hányadosaként számítják. Értéke megmutatja az egész gazdaságra jellemző árszínvonal-változást.
} 


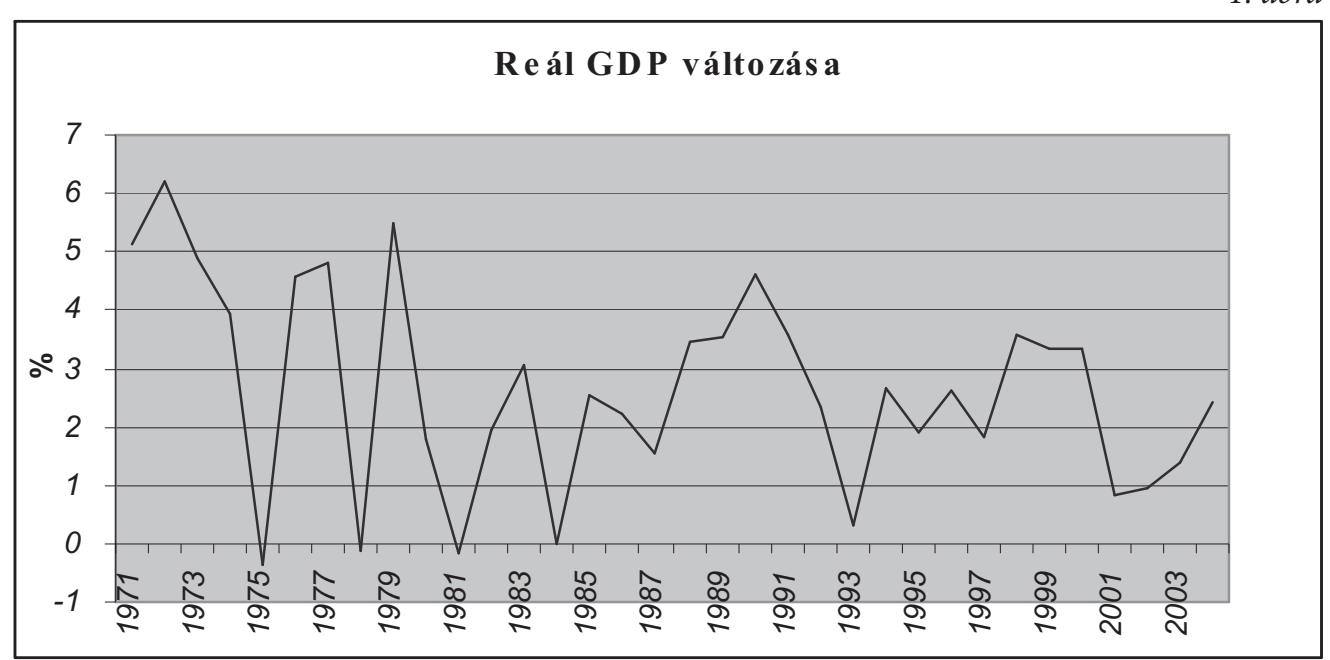

Forrás: OECD Statistical Database

2. ábra

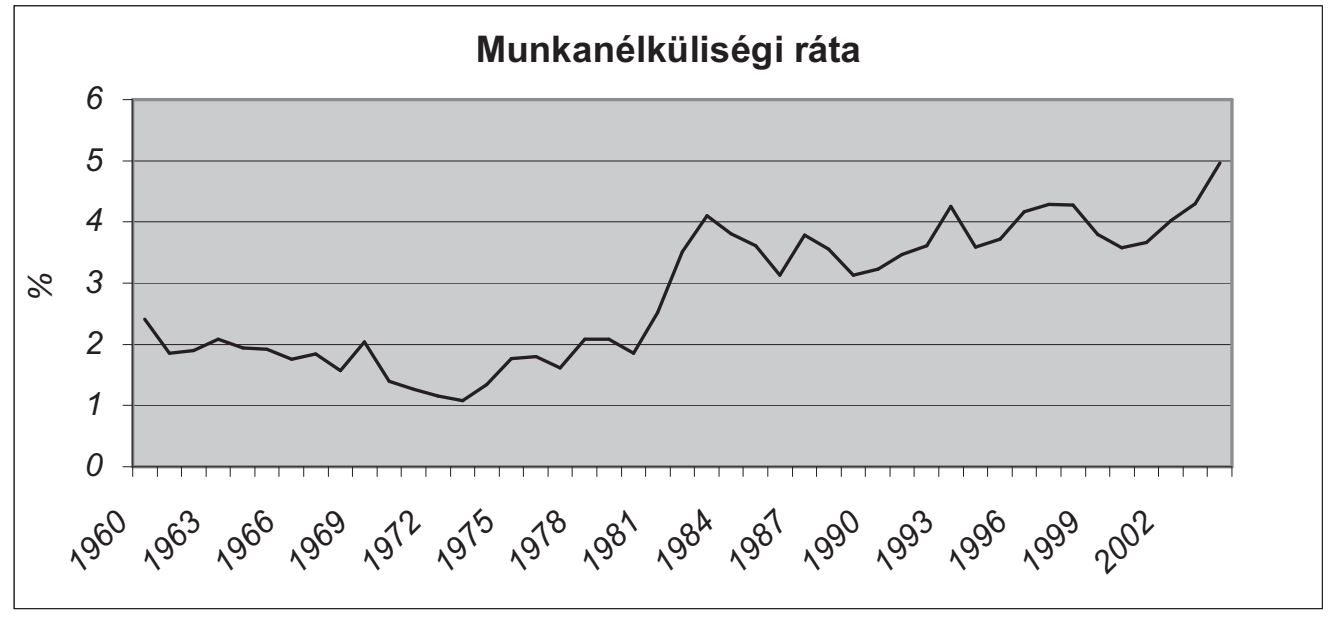

Forrás: OECD Statistical Database 


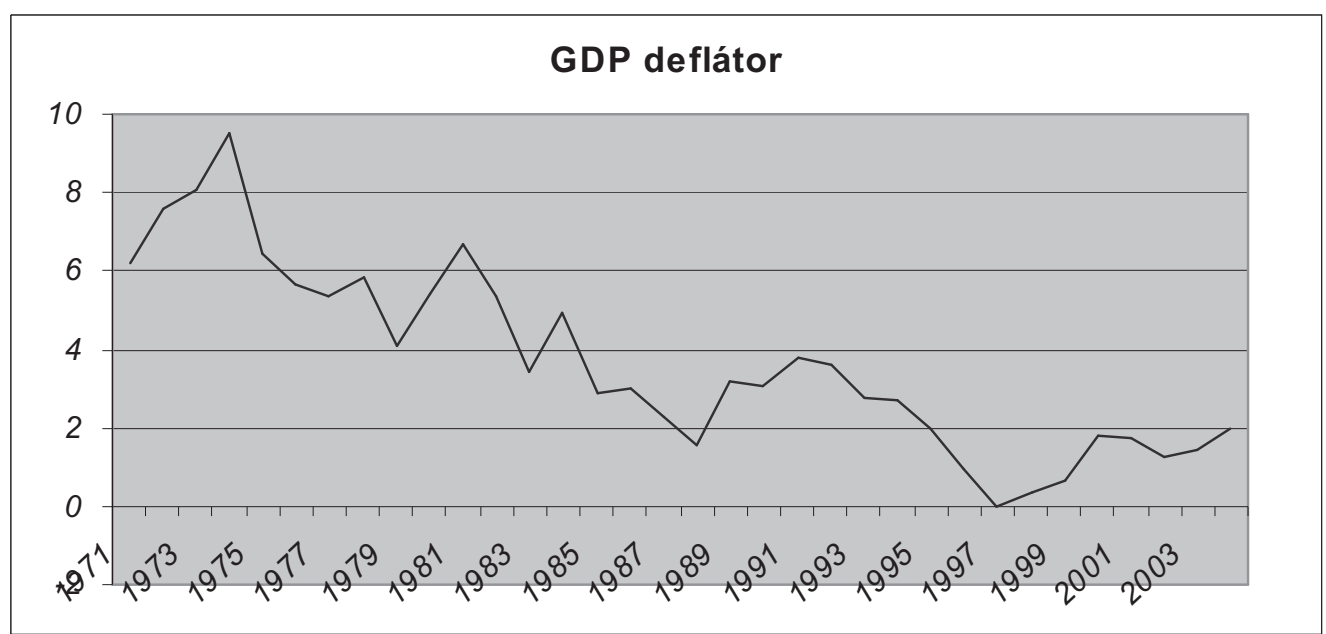

Forrás: OECD Statistical Database

Az osztrák gazdaságnak tehát az olajárrobbanást követő recesszióból úgy sikerült kilábalnia, hogy megtartotta a foglalkoztatás magas szintjét és az árszínvonal stabilitását. Az osztrák gazdaságpolitika emellett sikeresen tompította a konjunkturális ingadozásokat. ${ }^{9}$ Az ország gazdasági teljesítményének kedvező alakulásában az osztrák szociális partnerség intézménye is nagy szerepet játszott.

A gazdasági stabilizáció sarokköve volt, hogy a schillinget - stabilitása érdekében - 1971 elején a dollárral szemben felértékelték, majd Ausztria volt az első ország, amely valutájának lebegtetése mellett döntött. 1973 és 1976 között követték az európai országok egyezménye alapján kialakított valutakígyót, ${ }^{10}$ majd - több nyugat-európai ország gyakorlatához hasonlóan - a schillinget az egyik legkevésbé inflálódó valutához, a nyugatnémet márkához kötötték. A valuta stabilitása nagyban hozzájárult Ausztria kedvező nemzetközi megítéléséhez. A fizetési mérleg eredményének javításához az 1977-ben megtett intézkedések - belső kereslet csökkentése, export növelése - eredményesnek bizonyultak.

Az 1980-as évek elején azonban az osztrák gazdaságban strukturális problémák jelentkeztek, melynek eredményeként a növekedési ütem jelentős mértékben lelassult. Az árszínvonalat továbbra is kedvezőnek tekinthetjük, valamint a $4 \%$ körüli munkanélküliségi ráta is alacsonyabb az OECD átlagához képest. ${ }^{11}$ 1980-ban a schilling a dollárral szemben kissé felülértékeltté vált, így szükség volt az árfolyam korrekciójára. ${ }^{12}$

A 4. sz. ábra a schilling dollárhoz viszonyított éves átlagos átváltási arányát mutatja az 1980 és 2003 közötti időszakban.

9 A gazdaságpolitika céljai szinte azonosak voltak más jóléti államok politikájával. Ide sorolható a külső egyensúly biztosítása, a teljes foglalkoztatottság megvalósítása, gazdasági növekedés, pénzstabilitás.

101972 és 1977 között számos EK-országban a valuták egymás közti árfolyamát egy szűk sávon belül tartották, de más országok valutjáához képest az árfolyamok szabadon mozogtak. Ennek grafikus ábrázolása egy tekergő kígyóra emlékeztet.

${ }^{11}$ A foglalkoztatási szintre kedvezően hatott a munkaidő többszöri csökkentése, valamint az 1980-as évek elejétől bevezetett korkedvezményes nyugdíj intézménye.

12 Richter-Székffy (1987:25-62) felhasználásával. 
4. ábra

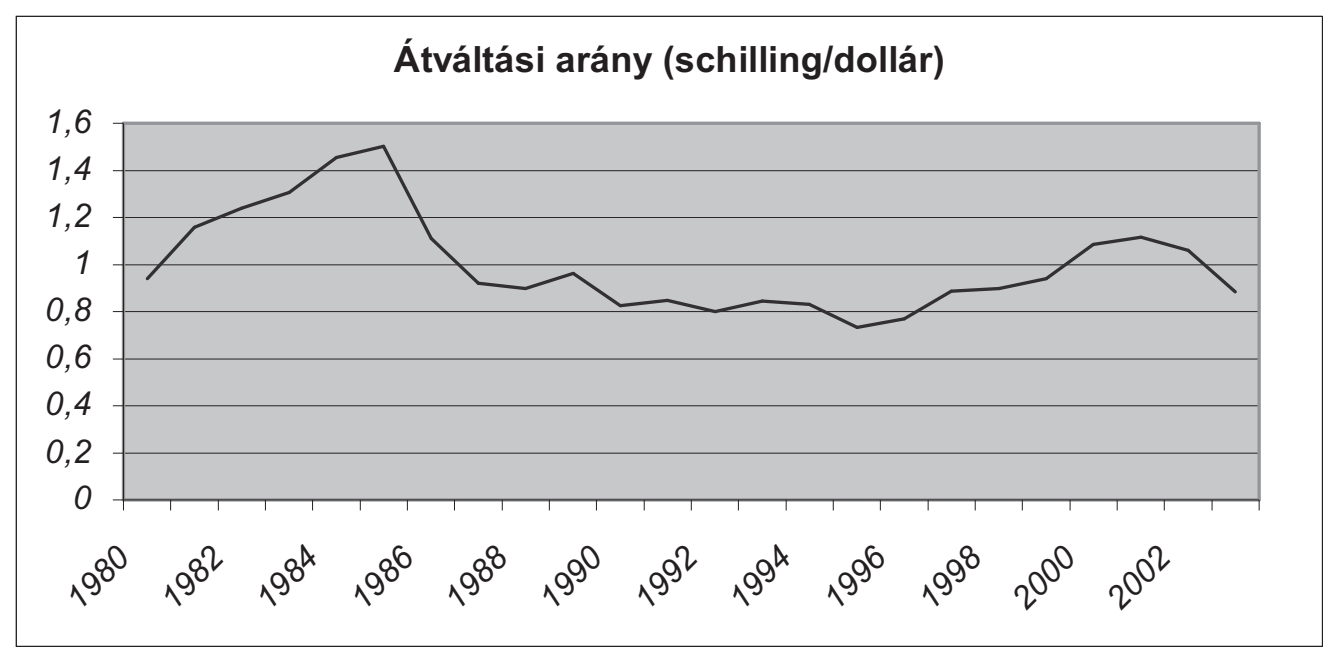

Forrás: OECD Statistical Database

A továbbiakban az 1970-es évek olajválságát követő gazdasági modell létrejöttében nagymértékben szerepet játszó társadalmi partnerség kialakulását és szerepét vizsgálom.

\section{Társadalmi partnerség és eredményei}

A társadalmi partnerség Ausztriában intézményesített kooperációnak tekinthető a munkapiac, az üzleti élet és a kormányzat között, amely magába foglalja a gazdaság- és társadalompolitika minden fontos aspektusát. ${ }^{13} \mathrm{Az}$ osztrák társadalmi partnerség jellemzője, hogy a résztvevők elsődleges célként a gazdasági növekedést és a teljes foglalkoztatást jelölik meg, míg a jövedelem elosztásával vagy az újraelosztással kapcsolatosan nem fogalmaznak meg célokat.

Az osztrák társadalmi partnerség fejlődésének és szerepének megértéséhez figyelembe kell vennünk az osztrák politikai és gazdasági rendszer fő jellemzőit. Elsőként említem a nemzetgazdaság kis méretét, mely egyet jelent az exporttól való erős függéssel, valamint az ország mérete maga után vonja a politikusok kisebb számát is, akik ráadásul folyamatos kapcsolatban vannak egymással. Ugyanakkor szükséges a sajátos történelmi és politikai fejlődés hangsúlyozása is, hiszen a történelemből való tanulás ritka - hazánkban inkább utópiaként ható - példájának tekinthetjük azt, hogy a második világháború után a korábban ellenséges pártok létrehozták

\footnotetext{
13 A nyugati iparosodott államok között Ausztria mutatta a legerősebb korporatív jellemzőket. Ez segítette hozzá Ausztriát, hogy az OECD-országok között itt éltek a legkevésbé a sztrájk eszközével. Az egy alkalmazottra eső sztrájk ideje Ausztriában 1965 és 1991 közötti időperiódusban 122,2 perc összesen, míg szintén a szociális korporatizmus példájának tekinthető Norvégiában ez a szám 707,5, Dániában pedig 2223. Liberális korporatív országokban, mint Svájcban 14 perc, Hollandiában 315 perc ugyanebben a periódusban, míg Belgiumban 1965 és 1980 között 1548 perc az egy alkalmazottra jutó sztrájk ideje összesen (Butschek 1991). Ez a helyzet csak 2000 februárjában, a néppárti-szabadságpárti kormány megalakulása után változott meg fokozatosan Ausztriában. Az elsőként hatalomra került Szabadságpárt szerint elérkezett az idő az eltérő érdekek nyílt ütköztetésén alapuló akaratnyilvánítás meghonosítására (Földvári 2001).
} 
a szociáldemokraták ${ }^{14}$ és konzervatívok nagykoalícióját. ${ }^{15}$ Ennek következtében a gazdasági és társadalmi együttműködés nagymértékben javult a két tábor változatlanul eltérő ideológiája ellenére. Az új gazdasági és társadalmi együttműködés - meglepő módon - éppen a nagy koalíció szétesésekor nyert igazi jelentőséget. ${ }^{16} \mathrm{Az}$ egyes pártokkal kapcsolatban álló gazdasági érdekscsoportok jelentős mértékben megtartották függetlenségüket és kiterjesztették az együttmüködést számos gazdasági és társadalmi kérdésre is. Megfigyelhető volt a megegyezésre törekvő, folyamatos gazdaságpolitika felé való elmozdulás, mely által az egypárti kormányzás kockázatai mérsékelhetőek voltak mind a kormányzó, mind az ellenzéki pártok számára. Végül fontos kiemelni, hogy az osztrák nemzetgazdaságban mind a külföldi tőke, mind az állami szektor lényeges érdekeltségekkel bírnak. ${ }^{17}$

Az osztrák társadalmi partnerség makroökonómiai szempontból vizsgált leglátványosabb sikerét 1968 és 1975 között érte el, amikor a gazdasági növekedés fenntartásában az osztrák export bérköltségeiben megmutatkozó komparatív előny megszerzésében nagy szerepet játszott a szakszervezeti bérpolitika. A bérek mérsékelt növekedése következtében ugyanis az osztrák gazdaság viszonylag gyorsan túljutott a világgazdasági válságon, valamint nagyban hozzájárult ahhoz, hogy az osztrák gazdaság az 1980-as években is megőrizte ezen a területen komparatív előnyét. ${ }^{18}$ A munkaerő-piaci gondok mérséklésére 1973 után fokozatosan csökkentették a vendégmunkások számát, 1975-ben 2 órával csökkentették a heti munkaidőt (40 órára), növekedett a részmunkaidőben foglalkoztatottak száma, korkedvezményes nyugdíjat vezettek be.

Mikroökonómiai szempontból azonban az osztrák társadalmi partnerség nem mutat a fentiekhez hasonló eredményességet. Ennek okaként egyrészt a nem hatékony erőforrás-allokációt nevezhetjük meg, másrészt pedig bizonyos szektorok és csoportok érdekében létrejött túlzott szabályozottságot. ${ }^{19} \mathrm{~A}$ két nagy párt hosszú koalíciója alatt kialakult jelentős pártbefolyás ${ }^{20}$ mellett Ausztria az egyesületek, az egyesülések, a különböző - természetesen polgári, civil - „titkos szervezetek” országává is vált. A szabadkőművesség a legmagasabb politikai, gazdasági szintekig ért, de például a katolikus diákegyesületek, a Burschenschaftok öregdiákjai is sajátosan összetartanak, egyengetik egymás útjait.

A társadalmi partnerség a 80 -as években elvesztette makroökonómiai befolyását és népzszerüségét, megváltozott a szerepe a politikaformálás területén, melynek jelentős hatása volt az osztrák korporativizmusra. Mára az osztrák gazdaságpolitikában makroökonómiai szinten már csak ritkán jelenik meg összehangolt érdekvédelem, szinte csak a bérpolitika, a munkajog és egyéb munkaerő-piaci kérdések területére korlátozva. A társadalmi partnerség makroökonómiai beszűkülése okának tekinthetjük, hogy az érdekegyeztetés előfeltételei a politika makroszintjén

14 1991. június 15-től az Osztrák Szocialista Párt névmódosítással felvette az Osztrák Szociáldemokrata Párt nevet.

15 Leopold Figl kancellársága (ÖVP) és Adolf Scharf (SPÖ) alkancellársága mellett három kormány, majd Julius Raab kancellársága mellett négy kormány is alakult.

16 Josef Klaus második kormánya már csak kizárólag néppárti tagokból állt (1966-1970). 1970-től 1983-ig Bruno Kreisky négy kormányt vezetett kizárólagosan szocialista párti alapon.

${ }_{17}$ Nowotny (1993) alapján.

18 Külön specifikumként említhető, hogy Ausztriában a társadalmi partnerség alapelveit külön jogszabályokban nem rögzítették, az együttmúködés kereteit az alapegyezmények jelentik.

${ }_{19}$ Az utóbbi években megindult változások közé sorolhatjuk azokat a mérsékelt lépéseket, melyek arra irányulnak, hogy lecsökkentsék a szubvenciókat, valamint deregulációs folyamatokat indítsanak el.

20 „Akarja tudni, mi az az osztrák arányossági rendszer? Ha az ember végigmegy az Argentinierstrassen (ahol egykor az osztrák rádió székháza állt), s kezet akar fogni a rádió egyik felelős vezetőjével, megdöbbenve tapasztalja, hogy hirtelen két kezet kell megráznia”. Ez a kijelentés az egykori osztrák kancellártól, Julius Raabtól származik 1956-ból, amikor a pártbefolyást igyekezett megvilágítani (HVG 1994b). 
megváltoztak. Amíg a különböző szövetségek és kamarák tagjainak szintjén az érdekhelyzetek heterogenizálódtak, a csúcsszervezetektől való növekvő távolságuk egyre inkább kritikai szemlélettel párosult. ${ }^{21} \mathrm{Ez}$ egyrészt megnehezíti a szövetségen belüli érdekegyeztetést, másrészt hatása van a szövetségek közötti viszonyokra is.

A fontos döntésekben (pl. nyugdíjreform) az utóbbi időben az eljárást és a tartalmi részeket a kormánypártok határozták meg, a szövetségeknek egyre inkább csak legitimációs funkciója van. $^{22}$

\section{Ausztria gazdasága a 80-as évek után}

Az 1980-as évek elején a nagy költségvetési deficit és a növekvő kormányzati adósság/GDP arány következtében a fenntarthatóan kiegyensúlyozott államháztartás (fiscal sustainability) kérdése lett a közgazdaságtan legégetőbb problémája. Annak az eldöntése, hogy az adott fiskális politika fenntartható-e, rendkívüli fontossággal bír a közgazdasági szakemberek és a politikusok számára egyaránt. Nem véletlen, hogy a kérdés megválaszolásával szakértő közgazdászok hada foglalkozik ma is. Ajánlásuk egyértelmü: az adott gazdaságoknak fegyelmezettebb fiskális politikát kell folytatniuk, fokozatosan csökkenteniük kell az adósság/GDP arányát, kezelni kell a népesség öregedéséből adódó problémákat, valamint olyan strukturális változásokra van szükség, melyek a piaci erők működésének bekapcsolását, a kormányzati szektor hatékonyabbá tételét, ${ }^{23}$ a költségvetési eljárás javítását ${ }^{24}$ és a fiskális kapcsolatok megreformálását ${ }^{25}$ feltételezik.

Ausztriában is csak a 80-as évek elején tudatosult a kormányzatban, hogy a fenntarthatóan kiegyensúlyozott államháztartás biztosítása szempontjából az államadósság szintje magasnak tekinthető. Az általános problémának számító magas adósságszinten túl - melyet jelentősége folytán külön fejezetben elemzek - azonban az osztrák demográfiai folyamatok változása is növekvő terheket ró a kormányzatra, így Ausztriának kiemelten szükséges kezelnie a jelentős népességöregedésből fakadó fiskális problémákat, mivel - becslések szerint - 50 év múlva várhatóan a 64 év felettiek aránya kétszerese lesz a jelenleginek. Természetszerüleg ez nemcsak növekvő nyugdíj- és egészségügyi kiadásokat jelent, hanem csökkenő adó- és társadalombizto-

${ }^{21}$ A változásokat jól jelzi az osztrák Munkáskamara (Arbeiterkammer) tevékenységének megváltozása. Az 1992-es reform óta ugyanis ingyenes jogszolgálatot nyújt, ösztöndíjakat oszt és lakásépítési garanciát nyújt, emellett kulturális fórumokat finanszíroz és könyvtárakat tart fenn (HVG 1994a).

${ }^{22}$ Richter-Székffy (1987:11-24), Richter-Székffy (1987:63-108), Tálos (2003), Földvári (1993) és Guger (1990) felhasználásával.

23 A közigazgatási reform részét kell képezze a közszférában való rugalmas munkavállalás megteremtése, valamint a közhivatalnokok nyugdíjrendszerének összehangolása az általános szabályokkal.

${ }^{24}$ Emellett pedig fejleszteni szükséges a fenntarthatóan kiegyensúlyozott államháztartás megteremtésére vonatkozó számításokat.

25 Tanzi (2000) megfigyelése szerint néhány országban a gazdasági tevékenységekre vonatkozó rendelkezések nagy részét nem a nemzeti, hanem a szubnacionális kormányzatok hozzák létre. Ezt azzal magyarázza, hogy a kormányzat összes szintje szükségességét érzi annak, hogy kiadásait növelje és néhány tevékenységet szabályozzon. Feltételezése szerint, a decentralizált kormányzatok müködésével és a normaalkotás több szintjének létrejöttével a szabályozások száma is megnő. Néhány szabályozás természetesen szükséges és hasznos, azonban néhány kevéssé szükséges vagy egyenesen káros hatású. Mindennek az oka tehát az, hogy minden egyes közigazgatási szint saját céljait igyekszik megvalósítani, és ez a szabályozásra is hatással van. Ezért - véleménye szerint - újabb kormányzati szintek létrejötte - regionális vagy helyi - valószínúleg a káros szabályozás mennyiségét növeli. Emellett említést érdemel az is, hogy egyrészt nehezebb biztosítani a fiskális transzparenciát, amikor a szubnacionális szintek nagy jelentőségűek és függetlenül müködnek a központi kormányzattól, valamint a decentralizált struktúra növeli az állami alkalmazottak számát és korlátozottak a lehetőségek a méretgazdaságosság előnyeinek kiaknázására. 
sítási bevételeket is. Mindez jelentős nyomást gyakorol a közfinanszírozási rendszerre mind a bevételi, mind a kiadási oldalon, aláásva a hagyományos jóléti állam finanszírozását. ${ }^{26}$

Az osztrák népesség korösszetételét a teljes populáció százalékos arányában a szemléltetés érdekében az 1956 és 2004 közötti időszak vonatkozásában az 5. sz. ábra mutatja be.

5. ábra

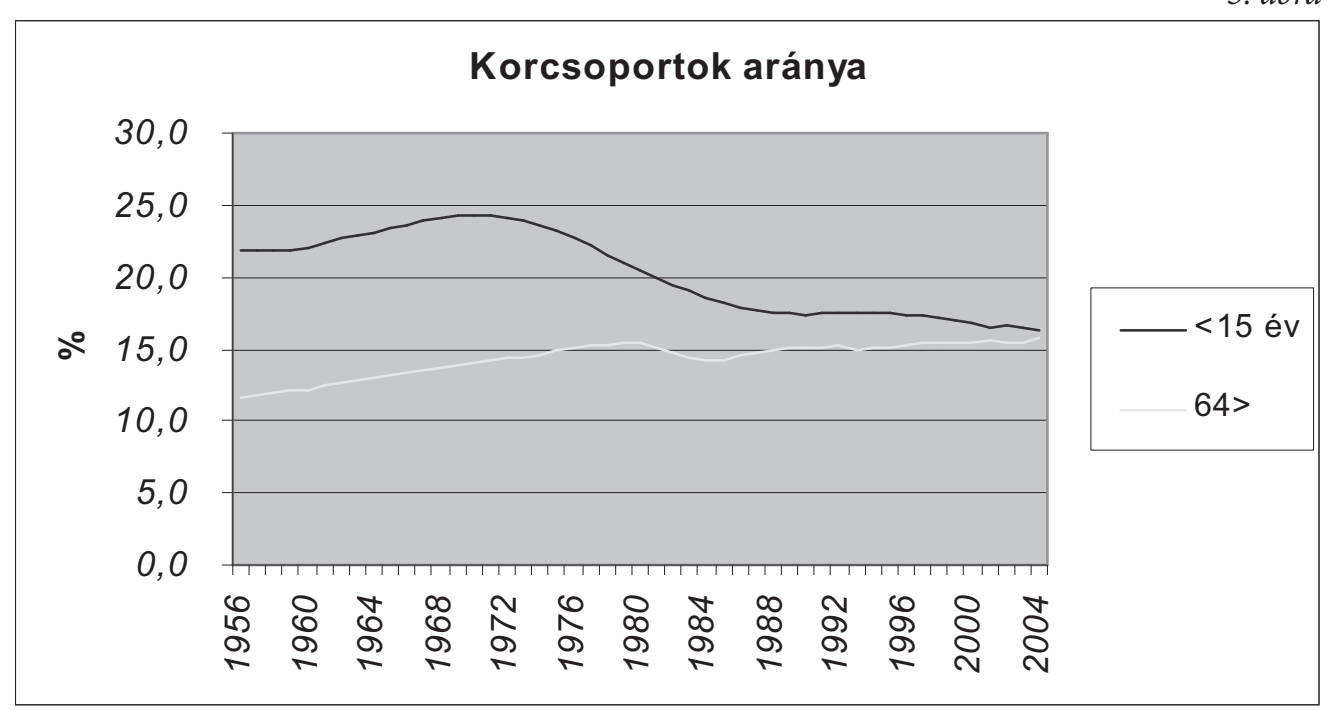

Forrás: OECD Statistical Database

Az ábrán látható, hogy a vizsgált periódusban a 64 év felettiek aránya fokozatosan nő, az 1956-os 11,6 \%-ról 2004-re 15,7 \%-ra, és ez a tendencia várhatóan folytatódni fog. Ezzel párhuzamosan pedig a 15 év alattiak részaránya az 1970-es évektől kezdődően fokozatosan csökken, 2004-ben 16,2 \%-ot ért el.

A demográfiai változásokkal szoros kapcsolatban álló munkanélküliség nagysága Ausztriában - melynek alakulása a 2. sz. ábrán látható - továbbra is alacsony, bár az 1970-es évek kezdete óta fokozatosan növekszik. A munkapiac általánosan jól működő, feszültségforrást főként a magas szezonális és a fiatalok körében megnövekedett munkanélküliség jelentett, miközben a hosszú távú munkanélküliség aránya még mindig alacsony. A munkanélküliségi ráta alacsonyan tartásának egyik eszközét az idősebb munkavállalók korai nyugdíjazása jelentette. ${ }^{27}$

A 6. sz. ábra az egy éven túli munkanélküliek százalékát mutatja be a teljes munkanélküliség arányában az 1994 és 2004 közötti időszakra vonatkoztatva.

\footnotetext{
${ }^{26}$ Eskesen (2002) alapján.

${ }^{27}$ Az osztrák munkapiac relatív rugalmas, de az idősebb munkaerő részvételi aránya a legalacsonyabbak között van az EU-ban.
} 


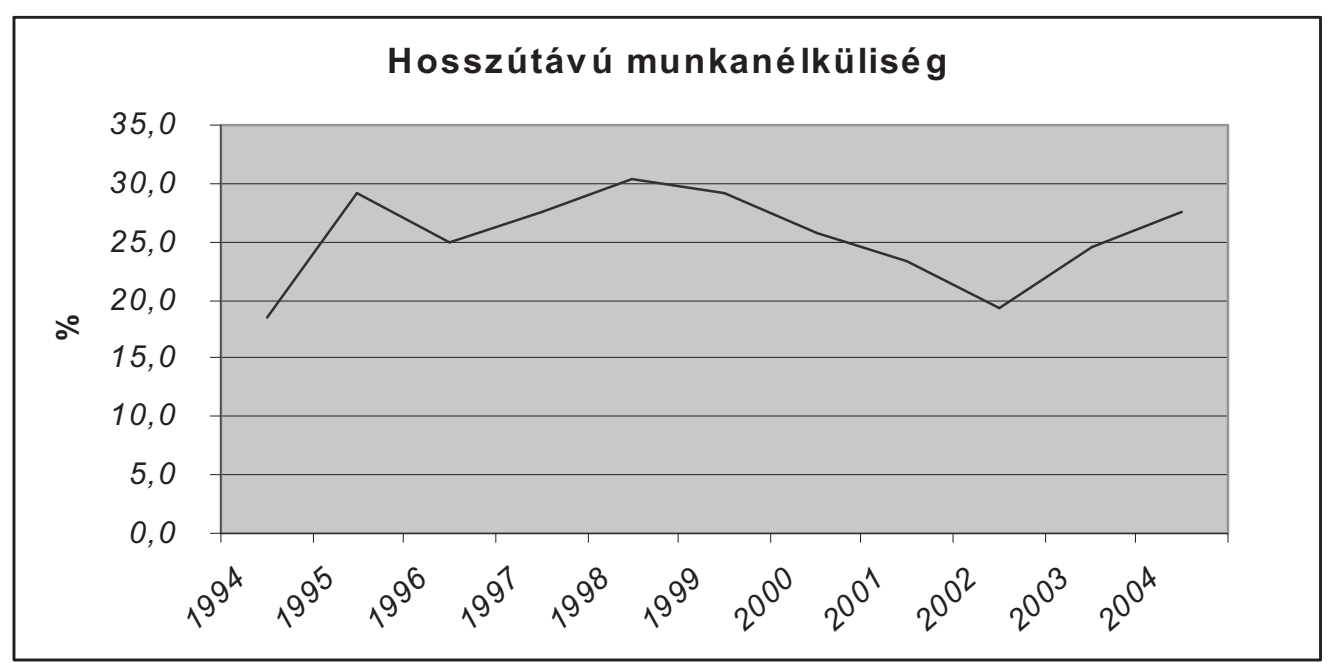

Forrás: OECD Statistical Database

A hosszas várakozások után 2003-ban elkezdett nyugdíjreform - a korábban kifejtettek miatt - értelemszerűen jelentősen javítja a hosszú távú fiskális pozíciót azáltal, hogy biztosítja a szükséges csökkenéseket a nyugdíjkiadásokban, annak ellenére, hogy a populáció öregedése nyomást gyakorol a nyugdíjrendszerre, és az növeli az egészségügyi és egyéb kiadásokat. Számos teendő maradt azonban még ezen a területen. Ide sorolható az egyes nyugdíjrendszerek harmonizációja - mely nemcsak az egyenlőtlenségeket csökkentené, hanem hosszú távon megtakarításokat generálna -, a rokkantsági nyugdíj rendszerének felülvizsgálata, valamint az idősebb dolgozók munkapiaci integrációjának elősegítése.

Jelentős gazdaságpolitikai problémára világít rá az is, hogy a kiskereskedelmi szektorban a rugalmasabb nyitvatartási időről 2003-ban ugyan végre törvényt alkottak, azonban a végrehajtás az államok hatáskörébe tartozik. ${ }^{28} \mathrm{~A}$ kereskedelmi szektoron kívül egyes hivatások gyakorlása is komplex szabályozás alatt áll, ide értve az állami rendelkezéseket és az önszabályozást is. A mindenre kiterjedő szabályozás egyrészt magasabb árakat eredményez, másrészt ezzel áll összefüggésben az is, hogy meglehetősen kevés a piacról kilépő vállalkozás száma. Mindezek fényében érthető módon alapvetően szükséges a szabályozás versenyre gyakorolt torzító hatásának minimalizálása.

Ausztriában meglehetősen nagy a nemzetközi versenynek kitett termelési folyamatok és a szolgáltatási szektor gazdasági teljesítménye közötti különbség. ${ }^{29}$ Míg a termelés teljesítménye jónak mondható nemzetközi összehasonlításban is, a szolgáltatói szektor teljesítménye átlag alatti, melyre elsősorban a túlzottan korlátozó szabályozás szolgálhat magyarázatául, és pusztán

\footnotetext{
${ }^{28}$ Bár a szövetségi kormányzat megteremtette a törvényes lehetőségét annak, hogy az egyes államok megnövelhessék a területükön müködö üzletek nyitvatartási idejét, ennek ellenére összességében az üzletek átlagos nyitvatartási ideje mégis itt a legrövidebb az EU-tagországok között.

${ }^{29}$ A termelékenység növeléséhez elengedhetetlen az oktatási rendszer hatékonyságának növelése, valamint az élethoszszig tartó tanulás ösztönzése.
} 
már a belépési korlátok csökkentése által elérhető lenne a verseny fokozása. ${ }^{30} \mathrm{~A}$ termékpiaci verseny erősödését tehát számos törvényi korlátozás eltörlése szolgálná, ami nemcsak a termelékenység javulását eredményezné, hanem a foglalkoztatás növekedését is, valamint növelné a fogyasztói jólétet. Néhány reformot már sikeresen bevezettek ezen a területen, de a számos, továbbra is meglévő jogi korlát a verseny gyengítését szolgálja. ${ }^{31} \mathrm{~A}$ versenytörvény és a kartelltörvény (2002) reformja éppen ezért különösen nagy lépést jelentett az európai fóáram irányába.

A szabályozási korlátok lebontása és a munkapiac kérdése hatásaiban a munkapiac liberalizációjának problémájában ér össze. A munkapiac liberalizálásának érdekében a hatóságok társadalmi párbeszédet kezdeményeztek a rugalmasabb munkaidő bevezetéséről, ami alacsoynyabb túlóradíjakat eredményezhetne. A magán-munkaerőközvetítők segítségével történő elheylyezkedést megtiltó törvényt 2001-ben eltörölték. A 2003-as költségvetésbe már belekalkulálták a képzés fejlesztésére és a reintegrációra irányuló intézkedéseket is, az idősebb munkavállalók nem bérjellegü munkadíját pedig lecsökkentették.

Ezenkívül egyéb intézkedésként természetesen szükséges a bürokrácia további csökkentése, a Szövetségi Versenyhatóság (Federal Competition Authority) szerepének erősítése, a privatizációs folyamatok folytatása és a kutatás-fejlesztés erősítése a gazdaság növekedési potenciáljának erősítése érdekében. ${ }^{32}$

\section{Fiskális kapcsolatok reformja}

Az utóbbi években részben a globalizáció hatásaként, részben a fenntarthatóan kiegyensúylyozott államháztartás szükségességére tett közgazdasági felismerés következtében az átalakuló jóléti államokban decentralizációs hullám söpör végig. A fiskális decentralizáció tehát mára igencsak divatossá vált mind az iparosodott, mind a fejlődő országok körében a közszektor teljesítményjavítása érdekében. Az általános feltételezés szerint, a helyi kormányzatok közelebb vannak az állampolgárokhoz, ezért fogékonyabbak a választókerületeik egyéni preferenciáira, valamint a közszolgáltatásokat is jobban meg tudják oldani, ${ }^{33}$ mint a központi kormányzat, mivel a távolság csökkenti és torzítja a döntéshozatalhoz szükséges információkat. Ez az érv elég erős ahhoz, hogy semlegesítse a méretgazdaságosságból származó előnyöket a közjavak biztosítása területén. Ha tehát ezeket az érveket elfogadjuk, akkor egyet kell értsünk azzal is, hogy a kisebb országok sikeresebbek a nagyobbaknál a népesség szociális szükségleteinek kielégítése területén. A közszektor újrastrukturálása érdekében azonban a decentralizáció mellett a kötelezettségek és a rendelkezésre álló fiskális eszközök összehangolása is szükséges.

\footnotetext{
${ }^{30}$ A villamossági szektor liberalizációja 2001-ben, a gázszektor liberalizációja pedig 2002-ben történt az EU irányelveinek megfelelően.

31 A kormányzat két lépésben megvalósította a nyugdíjrendszer reformját, valamint a közigazgatás rugalmasságának növelésére is tett lépéseket. Ezeken túl szükséges a rokkantsági járulékot igénylők képességeinek felülvizsgálata, valamint annak a lehetőségnek a megteremtése, hogy az adott állampolgár kötelezhető legyen az egészségi állapotának megfelelő munka elfogadására. Az adóreform csökkentette a társasági adót és a háztartások adóterheit, azonban szükséges az adórendszer egyszerüsítése, valamint torzító hatásának csökkentése. Indokolt a családok adóterheinek kiegyenlítésére szolgáló alap (Family Burden Eqalisation Fund) rendeltetési megjelölésének eltörlése és integrálása a szövetségi költségvetésbe (OECD 2005d).

32 OECD (2003a), OECD (2003b), OECD (2005a), IMF (2003) és IMF (2005) felhasználásával.

${ }^{33}$ Az Egyesült Királyságban (Skóciában és Walesben is) választottak a Blair-kormányzat alatt saját regionális parlamentet.
} 
Ez az elméleti keret azonban meglehetősen általánosan. Nem nyújt precíz meghatározást a kormányzat bármely szintjén nyújtott speciális termékek vagy szolgáltatások - mint például az oktatás, egészségügy - biztosításának eseteire, amelyekről a mai napig viták folynak. A kormányzat különböző szintjeihez tartozó feladatok ellátásához pedig fiskális eszközöket szükséges rendelni. Ennek legkézenfekvőbb módja az adószedés, de ezenkívül említést érdemel a föderális rendszer azon sajátossága, hogy lehetőség nyílik a rendelkezésre álló források elosztására a közszféra különböző szintjei között (kormányközi szubvención ${ }^{34}$ ). Ez abban az esetben válhat valóra, ha egy kormányzati szint adóbevételei meghaladják a kiadásait, és többletét átruházza más kormányzati egység számára a költségvetése egy részének finanszírozására. ${ }^{35}$

A közszektor tevékenységének vizsgálatához tehát szükséges áttekinteni a kormányzati szintek között meglevő komplex fiskális kapcsolatokat, hiszen a feladatok elosztása, illetve az ezt szabályozó alapelvek felülvizsgálata nagyban képes javítani a közszektor hatékonyságát. A kis önkormányzatok egybeolvasztása például a méretgazdaságosságból fakadó előnyök kiaknázását jelentené. Az önkormányzatok adóbeszedési jogosultságának kiterjesztése, az adómegosztási szabályok reformja, a költségvetési eljárási folyamat javítása által a közszolgáltatások kínálatát jobban összhangba hozhatná a helyi kereslettel és javíthatná az elszámoltathatóságot is.

Az osztrák szövetségi állam három kormányzati szintre tagolódik - a szövetség (der Bund), a tartományok (die Länder) és az önkormányzatok (die Gemeinden) -, melyeket önálló választott kormányzati intézmények, független döntéshozatal és költségvetési autonómia jellemez. A tartományok ${ }^{36}$ önálló törvényhozói hatalommal rendelkeznek, az önkormányzatok autonómiáját pedig helyi ügyekben az alkotmány is garantálja. A decentralizált döntéshozói hatalom lehetővé teszi a helyi érdekek szem előtt tartását. Mint a legtöbb föderációban, az adóbevételek itt is szövetségi szinten központosítottak, míg a kiadások decentralizáltak. ${ }^{37}$ Következésképpen a vertikális egyenlösítő transzferek mennek végbe, valamint szövetségi szinten a döntéshozatal koncentrációja figyelhető meg. A kiadások decentralizációjának szintjét illetően Ausztria középső pozíciót foglal el az OECD-országok között, ámbár a tartományok kiadásai némileg alacsonyabbak más szövetségi rendszerű tagállamokénál. ${ }^{38}$ Mivel a szövetségi fiskális kapcsola-

\footnotetext{
${ }^{34}$ A kormányközi szubvenciók fontos szerepet töltenek be a fiskális föderalizmusban, ami számos funkciót szolgálhat. Ilyen funkciók lehetnek a spillover előnyök internalizálása, a fiskális egyenlősités, az adórendszer általános javítása. A kormányközi szubvenciók két általános formája különböztethető meg. Az első a feltételes szubvenció (conditional grant), vagyis a források felhasználása bizonyos feltételekhez kötött, a második pedig a feltétel nélküli szubvenció (unconditional grant), amikor a felhasználás nincs korlátozva. A feltételes szubvenció a helyi szolgáltatások biztosításához nyújt segítséget, míg a feltétel nélküli szubvenció tipikusan a fiskális egyenlösítés céljaira alkalmas. Az ilyen transzferek alkalmazása elött szükséges megismerni az egyes tartományok, államok fiskális szükségleteit és fiskális kapacitásait (Oates 1999).

${ }^{35}$ Oates (1999) alapján.

${ }^{36}$ A tartományok alkalmazzák a három szint kormányzati munkavállalóinak legnagyobb részét, kb. 43\%-át, a szövetségi kormányzat és az önkormányzatok pedig a maradék 38\%, illetve 19\%-ot.

${ }^{37}$ Az államszervezet eltérő felépítése (centrális, decentralizált vagy föderális) a források eltérő központosítását engedi meg az államnak. Ezzel kapcsolatban találkozhatunk olyan elméletekkel, mely szerint a föderális rendszer erösen decentralizált struktúrájában az állami bürokrácia terjeszkedésére nagyobb lehetőség nyílik a politikai ellenőrző mechanizmusok gyengébb müködése miatt. Ezzel ellentétben olyan érvelésekkel is találkozhatunk, miszerint a centralizált forma eredményez magasabb kiadásokat. Gedeon (2000:103) nemzetközi összehasonlítások alapján azt a következtetést vonta le, hogy a decentralizált, föderalista államszerkezet korlátozza az állami kiadások növekedését, mert a különböző kormányzati szintek megakadályozzák azt. A centralizált államberendezkedés pedig több eszközzel rendelkezik a kiadásokat csökkentő reformpolitikák véghezvitelére.

${ }^{38}$ A kormányzati kiadások tartományi része 1985 és 2002 között növekedett, amíg az önkormányzatok része csökkent.
} 
tok nem nevezhetőek hatékonynak az erőforrások elosztásában, megreformálásuk kiemelkedő fontossággal bír, összekapcsolva a közszféra reformját a fiskális konszolidációval. ${ }^{39}$

Az osztrák szövetségi alkotmány (Bundes-Verfassungsgesetz) mellett az állam - a szövetségi állam és az egyes tartományok - pénzügyi viszonyait már 1948 óta külön pénzügyi alkotmányban (Finanz-Verfassungsgesetz) rendezi. A pénzügyi viszonyok alkotmányi szintủ szabáylyozása a szokásos államháztartási, önkormányzati stb. törvényekben rögzített, s ekképpen a többször és könnyebben változtatható normarendszer mellett szilárd alapját képezi az állam pénzügyi rendszerének. A rendszer sajátossága, hogy ezeket a pénzügyi alkotmányi rendelkezéseket mindenkor a négy évre érvényes pénzügyi kiegyenlítő törvény (Finanzausgleichgesetz, FAG) rendelkezései konkretizálják, ${ }^{40}$ amely definiálja a kormányközi kapcsolatokat. A törvény a szövetségi kormányzat, a tartományok és az önkormányzatok közötti megállapodás alapján születik. Meghatározza a kormányzat három szintje között megosztott adók típusát és az elosztási arányokat, ${ }^{41}$ valamint specifikálja a fő transzfereket a kormányzat szintjei között. A FAG azt is meghatározza, hogy milyen adófajtákat állapíthatnak meg önállóan a tartományok vagy az önkormányzatok. A megosztott adók - amelyeknek a beszedésére a szövetségi kormányzat jogosult - és a szövetségi kormányzat transzferei a szövetségi kormányzat alatt levő kormányzati szintek jelentős bevételi forrását jelentik. A transzferek nagy része meghatározott rendeltetésü, speciális programokhoz kapcsolódik. Az egyes programok megvalósításának gyakori megoldása az önkormányzatok és az állam közötti társfinanszírozás. A szövetségi kormányzatra jellemző bevételek újraelosztásának bonyolult rendszere ugyanakkor csökkenti az átláthatóságot.

Az alkotmányban rögzítve vannak azok a területek, ahol csak a szövetségi parlament hozhat törvényeket, ${ }^{42}$ a többi terület a tartományi törvényalkotás ${ }^{43}$ felelősségi körébe tartozik. A felelösségi területek azonban részben átfedésben vannak. ${ }^{44} \mathrm{~A}$ szövetségi alkotmány az összes kormányzati szinthez rendel pénzügyi forrásokat a kijelölt feladataik teljesítéséhez, valamint elöírja, hogy

\footnotetext{
39 Néhány évtizeddel ezelött a fiskális föderalizmus témaköre csupán csekély jelentősséggel bírt a közgazdasági irodalomban. Alexis de Toqueville azonban már több mint egy évszázaddal ezelőtt a fiskális föderalizmus meghatározása kapcsán lejegyezte, hogy a szövetségi rendszer létrehozásának elsődleges szándéka az országok eltérő méretéből fakadó különböző előnyöknek a kombinációja. A különböző elönyök realizálásához azonban szükséges feltérképezni, hogy mely kormányzati funkciók és hozzájuk tartozó eszközök működnek jobban centralizálva, és melyek a kormányzat decentralizált szintjén. Ez a hagyományos elmélete tehát egy általános keretet jelöl ki a funkciók átruházására a kormányzat különböző szintjein, és azokhoz alkalmas fiskális eszközöket is rendel. A központi kormányzat felelősségi körébe sorolja a makroökoómiai stabilizációt és a jövedelem újraelosztását. A kormányzat decentralizált szintjeinek feladata pedig a javak és a szolgáltatások biztosítása az egyéni választókerületek preferenciái és az adott körülmények függvényében. Ezáltal tudja a decentralizált szolgáltatás növelni a gazdasági jólétet.

${ }^{40}$ A törvény valójában egy paktum a szövetségi állam, az egyes tartományok, a városszövetségek és az egyéb települési szövetségek, önkormányzatok között.

${ }^{41}$ A legfontosabb típus a megosztott adók (gemeinschaftliche Bundesabgaben), úgymint a személyi jövedelemadó, társasági adó és az általános forgalmi adó, amit a szövetségi törvényhozás határoz meg. Más adóbevételek nem megosztottak, hanem helyi és tartományi kormányzatok rendelkezésére állnak (ausschliessliche Landesabgaben). Ezek a saját adók csak az önkormányzatok esetében játszanak jelentős szerepet, pl. a kommunális adó (Kommunalsteuer). Az ingatlanadó rátája az egyetlen jelentős adó, amit önállóan a szubnacionális kormányzat állapít meg.

${ }^{42}$ A szövetség felelősségi körébe tartozik a magasabb oktatási és a szakmai gyakorlati képzés, a szociális politika néhány területe, mint például a családok támogatása.

43 A tartományok felelőssége biztosítani a társadalmi jólétet, az egészséggondozást a kórházi szektorban, az általános és a középiskolai oktatás néhány területét, ide tartozik még a természetvédelem, az építési szabályok, regionális infrastruktúra tervezése. A helyi hatóságok feladata a helyi tervezés, a helyi infrastruktúra biztosítása, a helyi szociális szolgáltatások.

${ }^{44}$ Például mind az államok, mind a helyi kormányzatok felelősek az iskolák fenntartásáért.
} 
a kormányzat különböző szintjei kötelezettségeinek összhangba kell lennie a lehetőségeikkel (Konnexität). Jelenleg a kormányzati kiadások kb. 30\%-át a szubnacionális kormányzatok költik el.

A 2004-ben felállított Alkotmányozó Konvent (Österreich Konvent) intézményes keretbe helyezte az alkotmányos reformról szóló vitákat, lehetőséget adva a fiskális szövetségi kapcsolatok javítására. A konventben a kormányzat, a politikai pártok és a társadalmi partnerek is képviseltették magukat. Feladatuk az volt, hogy átfogó javaslatot tegyenek a szövetségi kapcsolatokat egyszerüsítő alkotmányos reformra, de az alkotmány módosításáról végül nem született konszenzus.

Az alkotmányos reformra pedig nagy szükség lenne, mert az elmúlt 10 évben összkormányzati szinten kiemelkedő szerephez jutottak az extra költségvetési egységek, ami tovább növelte a szövetségi fiskális kapcsolatok komplexitását, erősítve a transzferek növekedését a kormányzat és a nem kormányzati közszektor szereplöi között.

Önmagában már a konzultációs mechanizmus javításával számba kellene venni a pozitív és a negatív externáliákat, ezáltal generálva költségmegtakarítást más kormányzatoknak. Ezzel egyidejüleg ugyanakkor a szövetségi fiskális kapcsolatok alapjainak reformja is szükséges. A kormányzatok közötti bevétel elosztási rendszernek sikerült ugyan elérnie a jövedelem kiegyenlítés magas fokát, a rendszer azonban mára már túlzottan összetett és átláthatatlan. A szövetségi fiskális rendszer reformjának erősítenie kellene az összhangot a kötelezettségek és a bevételek között. Végül szükséges eldönteni, hogy mely szolgáltatásokat képes a magánszektor a kormányzati szektornál jobban ellátni, és a kormányzat melyik szintje alkalmas leginkább a közszolgáltatások nyújtására. ${ }^{45}$

\section{Az államháztartás}

Örökzöld közgazdasági aggálynak tekinthető az állam nagyságának növekedése, túlzott beavatkozása a gazdasági folyamatokba. Mint ismeretes, az állam részesedésének arányát a GDPből ideológiai megfontolások, a fejlettségi szint alakulása, valamint az ad hoc mérlegelések alakítják. Általánosan elfogadott nézetek szerint ennek az aránynak 20\% és 70\% között kell lennie. Ez nem lehet lényegesen kisebb, mert akkor megnő a valószínűsége a gazdasági növekedést bizonytalanná tevő gazdasági kilengéseknek. Az államháztartás jövedelmi részesedésének nem szabad ezt az arányt meghaladnia sem, mert az a vállalati beruházások jelentős mértékü kiszorítását okozza, és ez a fenntartható növekedés ütemének csökkenéséhez vezet. Az állami kiadások GDP-arányos nagysága Ausztriában a 90-es évek közepéig növekedett (amikor az EU-ban jelentősen visszaesett), 1995-ben érte el a csúcspontját (56\%-ot), majd 1996-tól fokozatosan csökkent, 2004-ben pedig a GDP 50\%-a volt. Ez egy erőteljesen újraelosztó államberendezkedésre utal, melyhez hasonló a skandináv államokban jelenik meg. A hasonlóság ugyanakkor ebben kimerülni is látszik, mivel a skandináv államokban az újraelosztás mértéke csökkenő tendenciát mutat. Svédországban például az elmúlt évtizedben 15\%-ot meghaladó csökkenést realizáltak, ami egyértelmü gazdaságpolitikai váltás jelent: a fenntarthatóan kiegyensúlyozott háztartás megvalósítását tüzték ki célul. ${ }^{46}$

\footnotetext{
${ }^{45}$ OECD (2005c), OECD (2003a) és IMF (2005) alapján.

${ }^{46}$ Bartha (2005:157) alapján.
} 
A 7. sz. ábra mutatja be az államháztartás kiadásainak alakulását az 1976 és 2004 közötti periódusban.

7. ábra

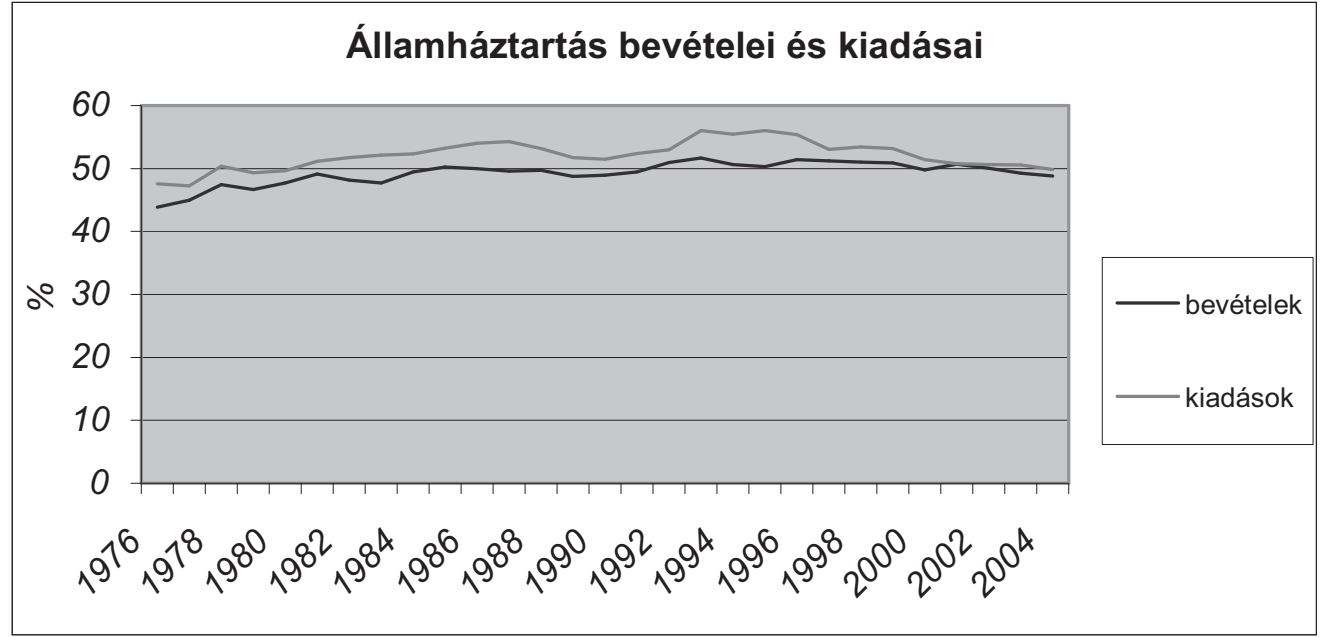

Forrás: OECD Statistical Database

A skandináv országok hagyományosan nagyobb kormányzati szektorral rendelkeznek, és ezzel párhuzamosan szociális kiadásaik is jóval nagyobbak nemcsak az ún. kontinentális országokban tapasztaltaknál, ahová Ausztria is tartozik, hanem az európai átlaghoz viszonyítva is. Náluk azonban az elmúlt 15 évben jelentős konvergencia tapasztalható a kiadások területén. ${ }^{47}$ Aiginger (2006) vizsgálata szerint a kontinentális és a skandináv országok bevételeinek elosztásában az 1990-es években meglévő 7\%-os különbség nem változott, azonban a közkiadások nagyságában levő különbség 4\%-ról 1\%-ra csökkent.

A fenntartható gazdasági növekedés megvalósításához nemcsak a technikai fejlődés megfelelő üteme, hanem az ahhoz szükséges beruházások megfelelő nagysága is előfeltétel, melyhez a kielégítő háztartási, vállalati és állami megtakarítás nélkülözhetetlen. Az egyik beruházást korlátozó tényező az állami hitelfelvétel, mivel az állam a tőkepiacon a vállalatok versenytársaként lép fel, ezért beszélhetünk az államnak a beruházásokat „kiszorító hatásáról”. A felhalmozott államadósság - hasonlóan az állami hitelfelvételhez - kapcsolatban van a beruházások kiszorításával, mert kamatterhekkel jár. Az államadósság után fizetett kamat nemcsak deficites, hanem egyensúlyban levő államháztartás esetén is veszélyezteti a szükséges beruházási ráta fenntartását, az eladósodottság pedig könnyen növekvő arányúvá válhat.

A 8. sz. ábra Ausztria adósságállományának 1980 és 2003 közötti alakulását mutatja be a GDP \%-ában mérve.

\footnotetext{
${ }^{47}$ Aiginger (2006) a kontinentális országok közé sorolta Olaszországot, Franciaországot, Németországot, Belgiumot és Ausztriát. A skandináv országok közé sorolta Dániát, Hollandiát, Svédországot, Finnországot és Norvégiát.
} 
8. ábra

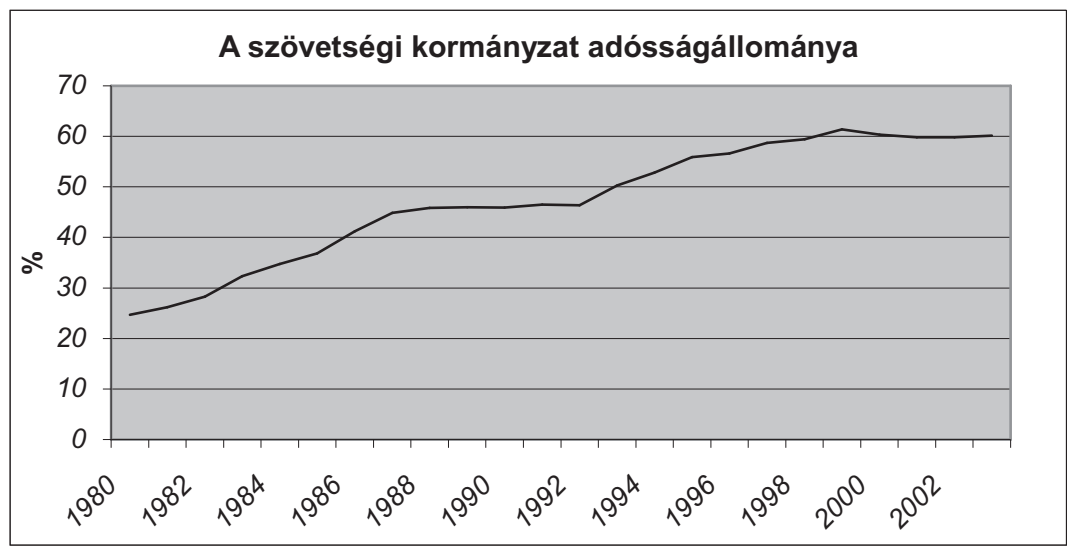

Forrás: OECD Statistical Database

Az ábrán látható, hogy míg a szövetségi kormányzat adósságállománya 1980-ban a GDP 24,7\%-át tette ki, 1999-ig fokozatosan nőtt, illetve akkorra érte el csúcspontját (61,41\%-ot), majd csökkenésbe kezdett. Ez a tendencia nagyban hasonlít a Hollandiában megfigyeltekhez, ahol az államadósság megugrása szintén a 80 -as évek elejére tehető. A felhalmozott adósság csökkentése (az elsődleges egyenleg szufficitje révén) rövid távon restrikciós hatású, ami nem kedvez a gazdasági növekedés ütemének. Kompromisszumos célt jelenthet tehát az államháztartási deficit GDP-hez viszonyított arányának fenntartása.

A 9. sz. ábrán látható, hogy az állami kiadások minél nagyobb részét teszik ki az államadósság után fizetett kamatkötelezettségek, melynek GDP-arányos nagysága 1996-ban érte el a csúcspontját (3,9\%-ot), majd fokozatos csökkenés után 2004-ben már csak 2,94\% volt.

9. ábra

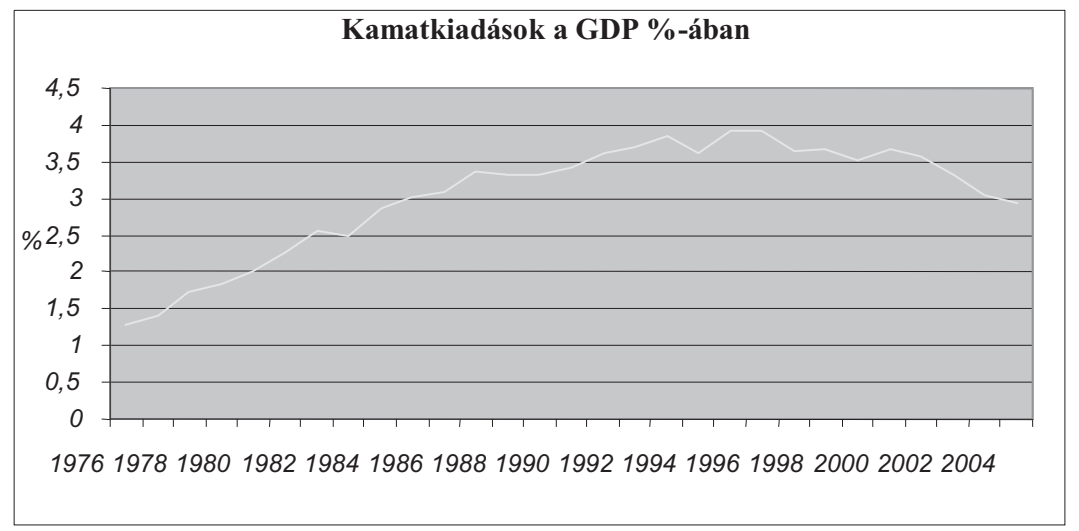

\section{Forrás: OECD Statistical Database}

A 10. sz. ábra Ausztria 1976 és 2004 közötti költségvetési egyenlegének alakulását mutatja be, melyen látható, hogy a deficit nagysága csökkenő. A szövetségi kormányzat költségvetésének egyensúlyát 2001-re - a tervezettnél egy évvel korábban - sikerült megteremteni,. Ezt 
nagy kiadási korlátozások nélkül, főleg a bevételek növekedésével valósították meg. Ez a megoldás szemben áll a közgazdasági irodalomban javasoltakkal. Ott ugyanis olyan érvelésekkel találkozhatunk, ${ }^{48}$ melyek azt hangoztatják, hogy a fiskális konszolidáció sikeressége ${ }^{49}$ nagyban függ a költségvetési korrigálások felvállalásától, valamint nagyobb valószínüséggel lesz sikeres a konszolidáció, ha elsősorban a költségek lefaragásával érik el, mintsem a növekvő pótlólagos bevételekkel. A kiadások általános kategóriáin belül pedig a különféle juttatásokban és a közszektor munkabéreiben végbemenő csökkenések valószínübben eredményeznek sikeres konszolidációt, mint a beruházási kiadások csökkenése. A beruházásokban megvalósuló csökkenés pedig azért jelent problémát, mert hátráltatja a gazdasági növekedést. Épp ezért kiemelkedő jelentőségű a közszféra reformjának - beleértve a társadalombiztosítási rendszer reformját - folytatása. Nem véletlen tehát, hogy a siker után 2002-ben ismét hiányt realizáltak.

10. ábra

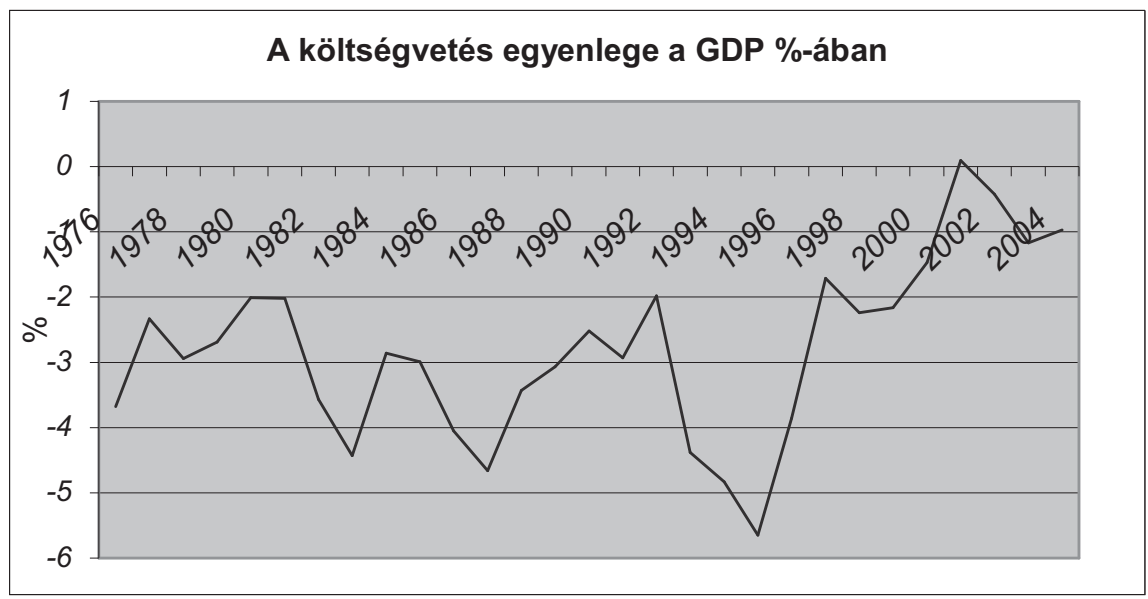

Forrás: OECD Statistical Database

Visszatérve a skandináv országokkal való hasonlósághoz, Aiginger (2006) a skandináv és a kontinentális államok elmúlt évekbeli gazdasági teljesítményét vizsgálva a legdrasztikusabb változást a költségvetési deficit alakulásában találta. A skandináv országokban a fiskális deficit a legmagasabb szintjét (5\%-ot) 1993-ban érte el, ezzel szemben 2005-ben 2,5\%-os többlettel zártak. A kontinentális modell országai - különösen Németország és Franciaország - alacsony deficittel rendelkeztek 1990-ben, de a csoport mindhárom nagy országának deficitje meghaladta a 3\%os szintet, és a csoport átlagát vizsgálva elérte a 3,5\%-ot. Ez jelenleg 6\%-os különbséget jelent a kontinentális és a skandináv modell országai között, mely világossá teszi, hogy sikeres a skandináv országok új stratégiája, melynek központi elemét jelenti a fiskális megfontoltság.

A 11. sz. ábra bemutatja, hogyan változott az osztrák államadósság összetétele - forgalomképes (marketable) és nem forgalomképes (non-marketable) adósságeszközök viz-

\footnotetext{
48 Von Hagen (2003) alapján.

${ }^{49}$ Ezekben az irodalmakban a sikert a fiskális konszolidáció hosszútávon való fenntartása jelenti, azaz a deficit arányának csökkenése nem tűnik el.
} 
szonylatában - összhangban a nemzetközi tendenciákkal. Napjainkra már a forgalomképes adósság teszi ki a teljes államadósság döntő hányadát.

11. ábra

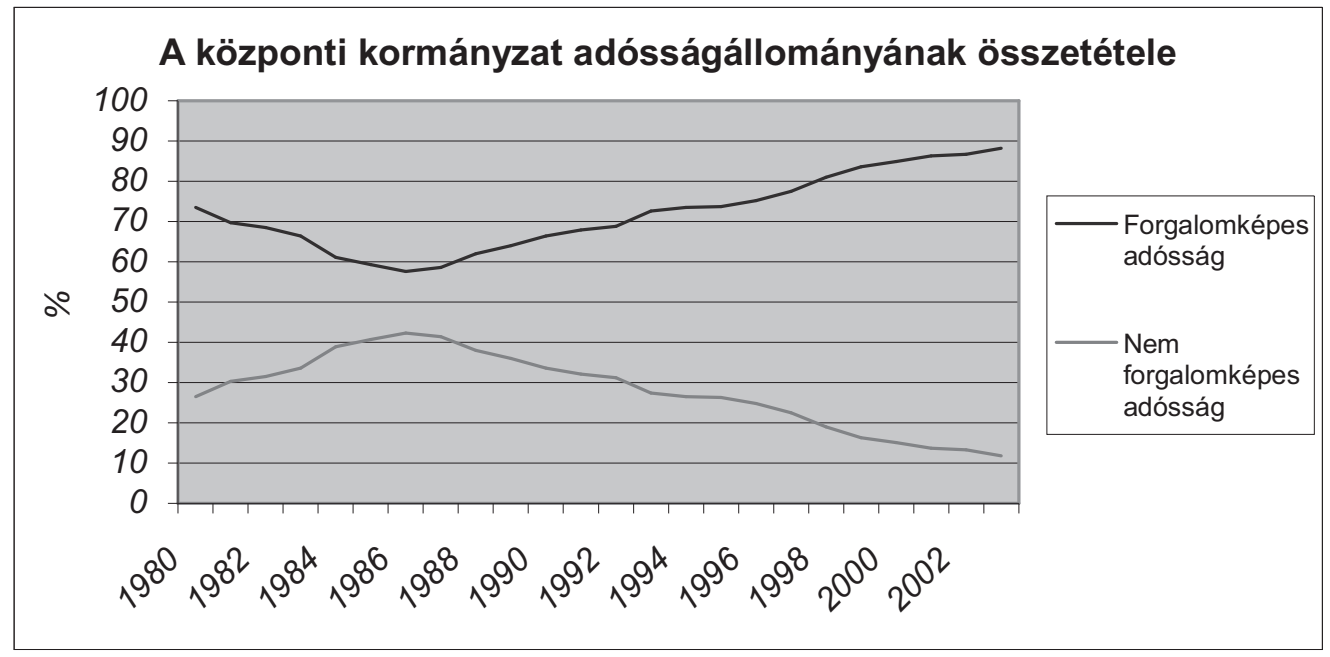

Forrás: OECD Statistical Database

A fenntarthatóan kiegyensúlyozott államháztartás azt feltételezi, hogy a kormányzat a végtelenségig képes folytatni a költségvetési politikáját, melyhez hozzátartozik a fizetőképesség kritériuma is. Szükséges különbséget tenni a fiskális és a külső fenntarthatóság (fiscal and external sustainability) kérdéskörében is. Éppúgy, ahogy nincs szükségszerűen közvetlen összefüggés a fiskális deficit és a folyó fizetési mérleg deficitje között, úgy nincs közvetlen összefüggés a fiskális és a külső fenntarthatóság között sem, bár a két tényező nem teljesen független egymástól. Létezik olyan eset, amikor a külső pozíció fenntarthatatlan, de a fiskális pozíció fenntartható. Ekkor a kormányzat a növekvő deficitjét a hazai adósság növelésével finanszírozza, ami elkerülhetetlenül kormányzati fizetésképtelenséget eredményezhet a hazai szolgáltatások területén. Ez az eset Ausztriában nem állhat elő, hiszen ahogy az a 12. sz. ábrán látható, mára az osztrák forgalomképes államadósságot - mely a teljes államadósság közel 90\%-át teszi ki - közel 70\%ban devizabelföldi tőke finanszírozza. 


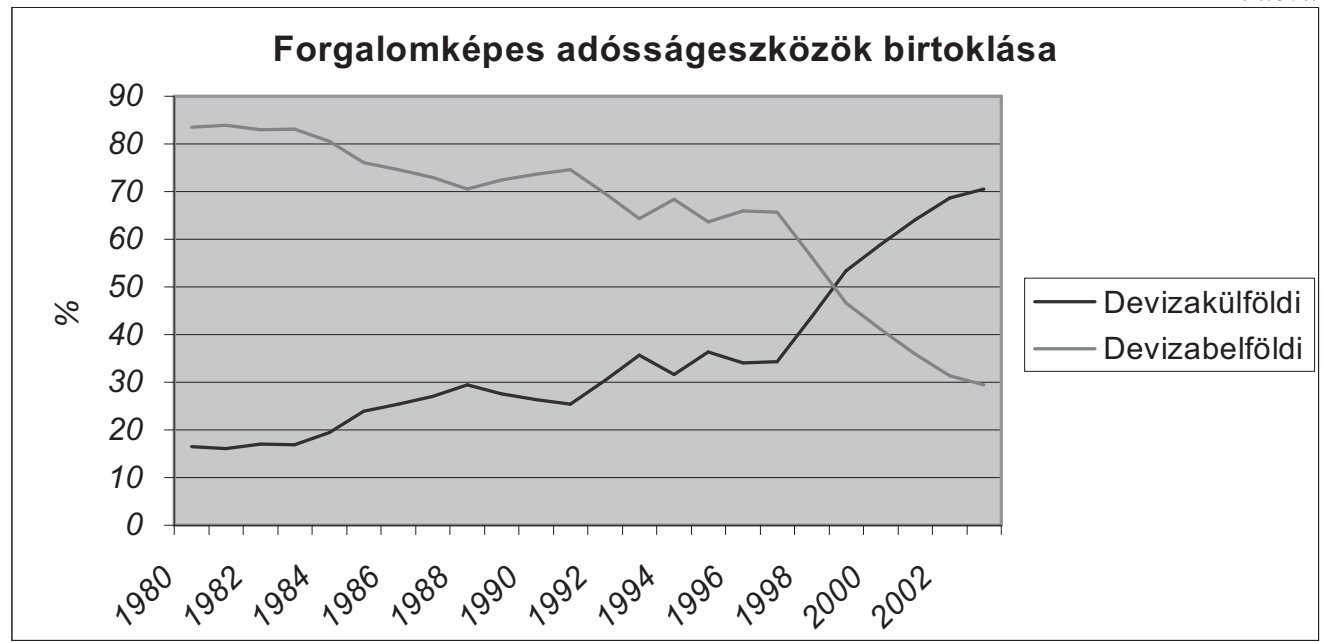

Forrás: OECD Statistical Database

Az osztrák államadósságot az 1992-ben alapított Osztrák Szövetségi Pénzügyi Ügynökség (Austrian Federal Financing Agency - AFFA) kezeli, amely az Osztrák Szövetségi Köztársaság nevében és javára jár el. Az osztrák szövetségi pénzügyi törvény (Austrian Federal Financing Act) 2. paragrafusa szerint az AFFA irányítja a kincstárat és kezeli az államadósságot, finanszírozza a költségvetés hiányát, részt vesz swap és más tranzakciókban, felkészül a szükséghelyzetek finanszírozására (Emergency Fund), tájékoztatja a pénzügyminisztert a kockázatkezelési stratégiáról és véleményt alkot a konszolidációs tervekről, melyen keresztül befolyásolja a szövetségi költségvetést. ${ }^{50}$ Az AFFA mellett az 1970-ben alapított Kormányzati Adósság Bizottsága (Government Debt Committee) szintén részt vesz a nemzeti adósság kezelésében. Feladatának tekinthető a jelenlegi és a jövőbeli pénzügyi és politikai szituáció elemzése, a pénzpiaci működés nemzetgazdaságra gyakorolt hatásának analízise, a költségvetési politika fenntarthatóságának analízise és az ezzel kapcsolatos ajánlások megfogalmazása, évenkénti beszámoló tétele a szövetségi pénzügyminiszternek, javaslattétel az adósságkezeléssel kapcsolatban. ${ }^{51}$

Bonyolítja a költségvetés politikai tervezését és értékelését, hogy nincs olyan érvényes középtávú keret, ami a bevételi és a kiadási tételek jövőbeli változásaival számolna. Emellett a kormányzatok közötti bevételmegosztás és a deficitcélok ellentétbe kerülhetnek a tartományok kötelezettségeivel. Ez nemcsak a kormányzati kiadások minőségét, hanem a fenntarthatóan kiegyensúlyozott államháztartás biztosítását is veszélyezteti. Emellett szükséges, hogy a költségvetési eljárás programorientált, a szövetségi közigazgatás pedig teljesítményorientált legyen. A törvényhozás az inputok parlamentáris ellenőrzésére kellene, hogy fókuszáljon, ellentétben a költségvetés program vagy tevékenység alapján történő felosztásával. 1980 óta, az osztrák gyakorlattal ellentétben, néhány OECD-ország - mint az Egyesült Királyság, az észak-európai államok, Új-Zéland, az Egyesült Államok - enyhítették az inputkontrollt, és újratervezték a költségvetési rendszerüket, ami immár az eredményekre fókuszál. Ebben az új rendszerben

\footnotetext{
${ }^{50}$ Austrian Federal Financing Agency honlapja alapján (http://www.oebfa.co.at).

${ }^{51}$ Lehner, G. (2002) alapián.
} 
a decentralizált menedzsmenteknek nagyobb a felelősségük a kitüzött célok teljesítésében. A költségvetési törvény megváltozott, egyszerüsítette a költségvetés felosztásának struktúráját. Az osztrák költségvetési rendszer további hibájának tekinthető, hogy míg a nagy elszámolási alapelvek érvényesek a kormányzat összes szintjére, ezek közül néhány nem teljesen harmonizál a különböző szintű kormányzatok között.

Az új koalíciós kormányzat ${ }^{52}$ célul tüzte ki a költségvetési egyensúly megvalósítását, 2010re az adóterhek a GDP 40\%-ra való csökkentését, a népesség öregedéséből adódó problémák kezelését, valamint Ausztria növekedési potenciáljának erősítését. Ennek keretében 2001-ben a szövetségi kormányzat, a tartományok és az önkormányzatok megállapodtak az első Belföldi Stabilitási Paktumban (Domestic Stability Pact - DSP) - az EMU stabilitási és növekedési egyezményéhez hasonlóan, - amely megtervezte az osztrák fiskális konszolidációs célok teljesítését. Ez előrehaladást jelentett az intézményi reform területén. A DSP-ben a szövetségi kormányzat, a tartományok és az önkormányzatok megegyeztek az egyensúlyi célokban a kormányzat három szintjére vonatkozóan, akárcsak az arra az esetre vonatkozó szankciókban, ha a pártok engedetlenséget tanúsítanak a célok elérésével kapcsolatban. A legutóbbi megállapodás a 2005-2008-as periódusra vonatkozik, melynek keretében a szövetségi kormányzat elkötelezte magát, hogy a deficitplafont a 2005-ös 2,4\%-ról 2008-ra 1,2\%-os szintre csökkentse, valamint megállapították az államok azon kötelezettségeit, miszerint 0,6\%-os szufficitet kell elérniük a 2005-ös és 2006-os évben, továbbá 0,7\%-ot 2007-ben és 2008-ban. Ezeket a célokat a kilenc tartomány összességére fogalmazták meg, ám a kevéssé gazdag államoknak kisebb többletet kell produkálniuk. A paktum értelmében az önkormányzatok kötelezettsége a költségvetésük egyensúlyban tartása négy éves periódusra vonatkoztatva, amely azonban szintén nem az egyes önkormányzatokra, hanem az önkormányzatok összességére, mint egységre vonatkozik. ${ }^{53}$

A 2001-ben és 2002-ben realizált rendkívül alacsony növekedési ütem, amikor a reál GDP növekedési rátája $0,8 \%$, illetve $0,96 \%$ volt, csak részben magyarázható a németországi stagnálás átgyürűző hatásával. ${ }^{54}$ Amíg a szociális kiadások növekedése, majd később a jövedelemadó csökkentése - az 2004-2005-ös adóreform keretében - növelte a háztartások rendelkezésre álló jövedelmét, a kedvezőtlen munkapiaci feltételek csökkentették a vásárlói bizalmat, ezzel mérsékelve a fogyasztási növekedést, növelve a háztartások megtakarításait. Megnőttek a magánberuházások, a reál-GDP növekedési üteme 2003-ban elérte az 1,4\%-ot, 2004-ben pedig a 2,4\%-ot. 2004-ben a hatóságok diszkrecionális fiskális lépéseket tettek, azaz 2003 végén egy olyan fiskális csomagot hirdettek ki, amely elsősorban a kutatásfejlesztést támogatta, és korábbra hoztak néhány olyan adóval kapcsolatos intézkedést, amelyet kezdetben 2005-re terveztek. Értelemszerüen ezek a lépések a tervezettnél nagyobb kiadásokat eredményeztek. A deficit mértékét eredetileg a GDP 0,7\%-ára tervezték, aztán az utólagos lépések eredményeképp, valamint az előnyugdíjazási programban résztvevő közhivatalnokok magasabb számának következtében a deficit 2004-ben 1,2\%-ra nőtt. 2005-ben és 2006-ban az adóreform és a költségvetési egyensúly iránti elkötelezettség között alakult ki feszültség. Az adóteher csökkentése növeli Ausztria vonzerejét, mint üzleti célpont, viszont nagyobb deficitet eredményez.

\footnotetext{
${ }_{52}$ Wolfgang Schüssel kancellár első kormánya az Osztrák Néppárt és az Osztrák Szabadságpárt koalíciójára épült (2000-2003), majd ezt a sajátos kapcsolatot vitte tovább módosult formában a ma is regnáló második Schüssel-kabinet (2003. február 28. óta).

${ }^{53}$ OECD (2005c) alapján.

${ }^{54}$ Ausztriában 2002-ben az árvíz okozta kár elérte a GDP 2\%-át.
} 


\section{Gazdasági integráció}

Az osztrák gazdaság az 1990-es években sikeresen aknázta ki a külső környezetben bekövetkező változások előnyeit, az EU- és az EMU-tagság pedig tovább erősítette az osztrák gazdaság regionális integrációját. Az Európai Unió keleti bővítése különösen fontos volt Ausztria számára politikai, biztonsági és gazdasági téren egyaránt. Ausztria korábban már sokat profitált az 1989. évi határnyitásból, a kelet-közép-európai rendszerváltásból. Az EU bővítésével pedig Ausztria az újra összekapcsolódó Közép-Európa centrumává vált, így egy fejlődőképes, jelentős gazdasági potenciállal rendelkező gazdasági térség központja lett.

Az EU15-ök között Ausztriának volt a leghosszabb keleti határa, mellyel egyenes arányban a kereskedelembővítésből származó haszna is a legnagyobb lett. Emellett pedig korán fókuszált a gazdasági és pénzügyi kapcsolatok építésére az újonnan csatlakozókkal, beleértve a banki, ipari és szállítási szektorokat. Míg kapcsolata a régi EU-tagállamok gazdaságánál gyorsabban fejlődő, újonnan csatlakozó országokkal erősödött, a hagyományos kereskedelmi partnereitől - különösen Németországtól - való függése csökkent. A Németország felé irányuló exportja az 1992-ben realizálódott 32\%-ról 2004-re 16\%-ra csökkent, bár még így is Németország maradt Ausztria legnagyobb kereskedelmi partnere. Németországgal való lazább kapcsolata következtében az osztrák és a német üzleti ciklusok kevéssé esnek egybe, mint korábban. A gyorsabb növekedésü országokkal való integráció pedig segíti a fenntartható gazdasági növekedés megvalósulását, valamint magasabb output-volatilitást jelent Ausztria számára.

A Németországba irányuló export csökkenését kompenzálja a már említett növekvő integráció az unióhoz újonnan csatlakozó kelet- és közép-európai országokkal: a velük folytatott külkereskedelem és a tőkekapcsolatok fellendülést adnak az osztrák gazdaságnak. A Visegrádi Országok térsége - melyhez Ausztriát erős történelmi múlt füzi - tekinthető az osztrák vállalkozók fö befektetési területének, az osztrák tőkekivitel egyharmada ezekbe az országokba irányul. ${ }^{55}$ Míg 1989 és 2000 között a kelet- és közép-európai országok importja az EU15-tagállamokból 1\%-ról 5\%-ra nőtt, addig az Ausztriából történő import 5\%-ról 13\%-ra. A csatlakozó országok - földrajzi közelségük révén - tehát egyrészt piacot jelenthetnek az osztrák termékeknek és szolgáltatásoknak, másrészt az osztrák beruházások célpontját is jelenthetik amellett, hogy növelik a versenyt. Fontos azonban hangsúlyozni, hogy az osztrák vállalatok belföldi piacát mesterséges belépési korláttal védték még az 1995-ös EU-csatlakozás után is. ${ }^{56}$

Az osztrák gazdaság nyitottságának, a világgazdaságba való integrálódásának mértékét a 13. sz. ábra mutatja az 1970 és a 2004 közötti időszakra vetítve. ${ }^{57}$

\footnotetext{
55 1999-ben az osztrák tőkekivitel első célpontjává Magyarország vált, ami az osztrák működőtőke-export egyötödét teszi ki.

${ }^{56}$ Körösi (2004), IMF (2005) és Epstein-Tzanninis (2005) alapján.

57 A kereskedelem és a GDP arányára vonatkozó jelzőszám: az export és import összege elosztva a GDP-vel. A mutatót gyakran nevezik kereskedelmi nyitottság hányadosának (OECD Statistical Database).
} 


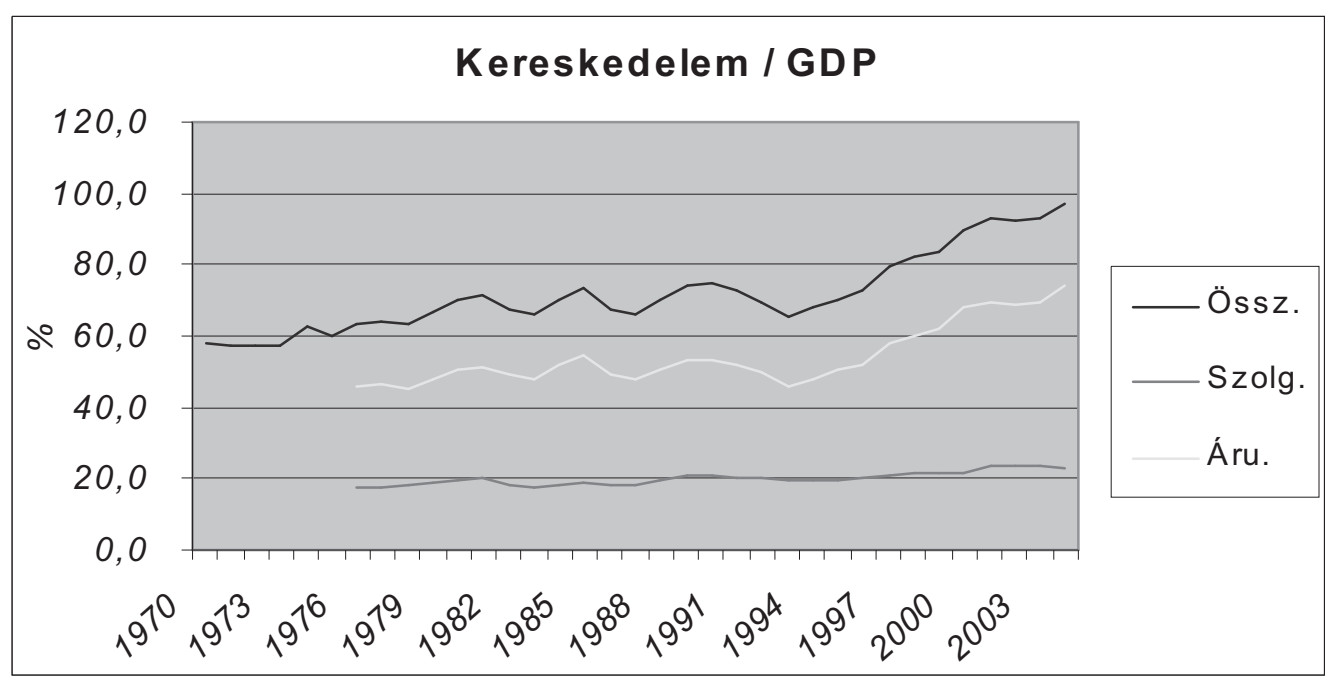

Forrás: OECD Statistical Database

Az ábra bemutatja a teljes kereskedelmi tevékenység, az áru kereskedelme és a szolgáltatások kereskedelmének összesített súlyát a gazdaságon belül, valamint a hazai termelők külföldi piacoktól való függésének mértékét. Látható, hogy a teljes kereskedelmi tevékenység és az áruk kereskedelme a GDP arányában fokozatosan nő, míg a szolgáltatásoké $20 \%$ körüli értéket vesz fel az egész vizsgált periódus alatt.

Ausztria mint kis nemzetállam 2000-től különutas stratégiát - regionális nagyhatalomtól való eltérés stratégiája - valósított meg, ezzel hangsúlyozta kivételességét. ${ }^{58}$ A különutas stratégia valójában a kényszerpályára kerülés pozitív kihasználását jelentette. Mint közismert, az 1999-es választások után az osztrák néppárti vezető, Wolfgang Schüssel nem folytatta a korábbi néppárti-szocialista nagykoalíciós gyakorlatot, ${ }^{59}$ hanem Jörg Heider Szabadságpártjával - gazdaságpolitikailag radikális-liberális beállítottságú szélsőjobb párt - lépett koalícióra, amely kiváltotta az Európai Unió diplomáciai bojkottját. Ausztria túlélte a bojkottot, a kényszerszülte külön út sikert hozott: reformokat és a növekedési ütem felgyorsulását, Haider marginalizálódását, a gazdaságot pedig fiskális konszolidáció és a liberalizáció felé orientálta. ${ }^{60}$

Lényegében ez a gazdasági integrációhoz kapcsolódó különutas politika adja meg a választ a belső változások bekövetkezésének időpontjára, illetve önmagában a változás lehetőségének megteremtődésére. Korábban a megfáradt nagykoalíció nem mert, vagy nem akart az államháztartást meghatározó alappillérekhez nyúlni, erejéből csak a megfontolt módosításokra, toldozásra-foltozásra telt. A politikában bekövetkező, osztrák viszonylatban radikális váltás, majd az ehhez kapcsolódó külső nyomás olyan belpolitikai helyzetet teremtett, mely nem csak lehetővé, de szükségszerűvé is tette az eddig halogatott reformintézkedések megkezdését. Lényegében az a furcsa helyzet állt elő, hogy az osztrák gazdaságot lendületbe hozó, az osztrák gazdaság számára végre pozitív változást jelentő intézkedéseket közvetetten egy külső negatív hatás váltotta ki. A külföldön sokszor elítélt, radikális jobboldalisággal vádolt kormányzat befelé, az ország gazdasága felé mint megmentő, gazdasági reformkormányzat jelent meg. 


\section{Konklúzió}

Az osztrák gazdaságot a háború utáni újjáépítési periódusban viharos gazdasági expanzió jellemezte, az ezt kísérő inflációt pedig az 1951-52-ben végrehajtott stabilizációs intézkedések fékezték meg véglegesen. A korabeli sajtó által osztrák csodának nevezett jelenség 1953-ban kezdődött és 1954-ben bontakozott ki. Az 1967-68-as recessziót követő fellendülés végét az 1973-as energiaár-robbanás jelentette, ami egyben egy hosszú fejlődési szakasz vége is volt. Az osztrák gazdaságnak az olajárrobbanást követő recesszióból úgy sikerült kilábalnia, hogy megtartotta a foglalkoztatás magas szintjét és az árszínvonal stabilitását. Mindemellett sikeresen tompították a konjunkturális ingadozásokat. A fejlett ipari országok átlagánál dinamikusabb gazdasági növekedés pedig a figyelem központjába állította az osztrák gazdaságot. Az érdeklődés miatt ekkor került széles körü vizsgálat alá az osztrák modell, azaz az osztrák gazdaságpolitika és az intézményrendszer. Ezen teljesítmény magyarázatára a társadalmi partnerség intézménye szolgálhat, amely intézményesített kooperációnak tekinthető a munkapiac, az üzleti élet és a kormányzat között, s amely magába foglalja a gazdaság- és társadalompolitika minden fontos aspektusát.

Az 1980-as évek elején Ausztriának is szembe kellett néznie a költségvetési deficit aggasztó mértékével és a növekvő kormányzati adóssággal, mely világossá tette, hogy az eddig folytatott gazdaságpolitika nem fenntartható. A közgazdászok ajánlása egyértelmü volt: fegyelmezettebb fiskális politikát kell folytatniuk, fokozatosan csökkenteniük kell az adósság/GDP arányát, kezelni kell a népesség öregedéséből származó problémákat, valamint strukturális változásokat kell végrehajtani, melyekhez a piaci erők müködésének bekapcsolása, a kormányzati szektor hatékonyabbá tétele, a költségvetési eljárása javítása és a fiskális kapcsolatok megreformálása szükséges. A felsorolt feladatok végrehajtását segítette, hogy a választópolgárok elégedetlenségét és a nagy pártok népszerüségvesztését érzékelve az osztrák néppárti vezető, Wolfgang Schüssel az 1999-es választások után nem folytatta tovább a korábbi néppárti-szocialista nagykoalíciós gyakorlatot, hanem a Szabadságpárttal lépett koalícióra, és egy egyedi, különutas politikát valósított meg.

A különutas politika gazdaságpolitikai programja keretében egyrészt a szolgáltatói szektor teljesítményének növelése érdekében tettek kezdőintézkedéseket, azonban a további liberalizáció, a szabályozás versenyre gyakorolt torzító hatásának minimalizálása lenne szükséges; másrészt a cselekvés szintjére hozva konstatálták, hogy a termékpiaci verseny erősödését is a számos törvényi korlátozó eltörlése szolgálná, ami nemcsak a termelékenység javulását eredményezné, hanem a foglalkoztatás növekedését is, valamint növelné a fogyasztói jólétet. Bár néhány reformot már sikeresen bevezettek ezen a területen is, a jogi korlátozások még továbbra is a verseny gyengítését eredményezik. Jellemző versenyélénkítő mozzanat, hogy az üzletek rugalmasabb nyitvatartási idejét 2003-ban törvényi szabályozással tették lehetővé, azonban a törvény tényleges megvalósítása az államok hatáskörében maradt, mely a gyakorlatban a végrehajtás elodázását eredményezte. A versenytörvény és a kartelltörvény reformja (2002) ugyanakkor nagy lépést jelentett az európai fóáram irányába. A 2003-ban megkezdődött nyugdíjreform szintén jelentősen javítja a hosszú távú fiskális pozíciót, azonban számos teendő maradt ezen a területen is. Ide sorolható az egyes nyugdíjrendszerek harmonizációja, a rokkantsági nyugdíj rendszerének felülvizsgálata, valamint az idősebb dolgozók munkapiaci integrációjának elősegítése. A Belső Stabilitási Paktumot 2001-ben fogadták el, melynek keretében a megfogalmazott konszolidációs célok jelentős előrehaladást jelentettek az intézményi reform területén, azonban a költségvetési egyenleg csupán 2001-ben került átmeneti egyensúlyba. Szükséges tehát a fiskális teljesítmény további javítása, illetve a költségvetési eljárás reformjának megvalósítása. A fenntarthatóan ki- 
egyensúlyozott államháztartás, illetve a fenntartható gazdasági növekedés feltételeinek biztosítása érdekében a kormányzati szektor karcsúsítására tettek ugyan lépéseket (2000-2004), azonban szükséges a szövetségi fiskális kapcsolatok és a kormányzati szektor hatékonyságának növelése is, emellett pedig - társadalmi igényt kielégítve - magasabb minőségü közszolgáltatás nyújtása. A 2004-ben felállított Alkotmányozó Konvent intézményes keretbe helyezte az alkotmányos reformról szóló vitákat, lehetőséget adva a fiskális szövetségi kapcsolatok javítására, konszenzus azonban nem született a szövetségi kapcsolatokat egyszerűsítő alkotmány módosításában.

Ausztriában a fiskális konszolidáció nagyrészt a GDP-arányos kormányzati bevételek növelésével valósult meg kiadáscsökkentő intézkedések helyett. A fiskális menedzsment hatékonyságának növelése mellett szükséges a már hivatkozott kormányközi kapcsolatok racionalizálása, az elszámoltathatóság erősítése, a kormányzat különböző szintjei funkcióinak korszerüsítése, megtakarítások generálása. A középtávú költségvetési keret bevezetése az összes kormányzati szinten és a költségvetés átláthatóvá és eredmény-orientálttá tétele segítene a fent megfogalmazott célok elérésében.

Az 1980-as években megkezdődött privatizációs program hozzájárult a magasabb ütemü gazdasági növekedés megvalósulásához, azonban az állami tulajdon aránya még mindig magas maradt, ami további reformokat tesz szükségessé. ${ }^{61}$ Ugyancsak kihívásokat jelent az idősebbek körében tapasztalható alacsony munkapiaci részvétel, valamint a magas szezonális inaktivitás. A megfelelő innovációs környezet biztosításához és a termelékenység növekedéséhez szükséges az oktatási rendszer hatékonyságának javítása, valamint az élethosszig tartó tanulás fontosságának hangsúlyozása. Végül a versenykörnyezet javítása tekinthető kiemelkedő fontosságúnak alacsonyabb belépési korlátok alkalmazásával és a vállalkozókat érintő adminisztratív terhek csökkentésével.

Strukturális szempontból tehát a kormányzati reformterv jelentős részének teljesítése ellenére maradtak olyan területek, melyeket a reformok még nem értek el, vagy a megkezdett reformokat még nem fejezték be. Összességében megállapítható, hogy az 1999-ben hatalomra került néppárti-szabadságpárti koalíció jelentős kísérletet tett a hagyományos jóléti állam megreformálásra, melynek vannak ugyan komoly gazdaságpolitikai eredményei, de nem sikerült kialakítania a fenntarthatóan kiegyensúlyozott államháztartás feltételrendszerét.

\section{Hivatkozások}

Aiginger, K.-Guger, A. (2006): The ability to adapt: Why it differs between tha scandinavian and continental european models? Intereconomics, Január-február, 14-23.

Austrian Federal Financing Agency. Letöltés helye: http://oebfa.co.at, Letöltés ideje: 2006. május 31.

Bara Zoltán-Szabó Katalin (2000): Gazdasági rendszerek és intézmények. In: Bara Zoltán-Szabó Katalin (szerk.): Gazdasági rendszerek, országok, intézmények. Aula, 53-77.

Bartha Attila (2005): Visszajáró svéd kísértet? Egy félreértés fogságában: a svéd modell álma és a kelet-európai realitás. Competitio, Debreceni Egyetem 2005/1, 153-163.

Bundeskanzleramt Österreich. http://www.austria.gv.at/site/3355/default.aspx, Letöltés ideje: 2006. szeptember 18.

Butschek, F. (1991): Institutional continuity and economic growth - the case of Austria. WIFO, Working Paper, 115/1999.

Eskesen, L. L. (2002): Population aging and long-term fiscal sustainability an Austria. IMF Working Paper 02/216.

Epstein, N.-Tzanninis, D. (2005): Austria: Selected issues. Intrnational Monetary Fund, Country Report 05/249, 40-47.

Gedeon Péter (2000): A modern kapitalizmus. In: Bara Zoltán-Szabó Katalin (szerk.): Gazdasági rendszerek, országok, intézmények. Aula, 81-125.

Földvári Zsuzsa (1993): Szalonképtelen képviselők. Heti Világgazdaság 1993/26. Letöltés helye: http://archivum.hvg. hu/Search.aspx?q=szalonk\%C3\%A9ptelen+k\%C3\%A9pvisel\%C5\%91k\&qhas=\&kw=\&fd=1993.01.01\&td=2006.11.14, Letöltés ideje: 2006. november 14. 
Földvári Zsuzsa (2001): Osztrák szakszervezetek. Heti Világgazdaság 2001/38. Letöltés helye: http://archivum.hvg.hu/ Search.aspx?q=osztr\%C3\%A1k+szakszervezetek\&qhas=\&kw=\&fd=2001.01.01\&td=2001.12.31, Letöltés ideje: 2006. november 14

Guger, A. (1990): Corporatism: Success or Failure? Austrian experiences. WIFO, Working Paper, 1990/36.

HVG (1994a): Munkáskamara varieté. Heti Világgazdaság, 1994/48, Letöltés helye: http://archivum.hvg.hu/Search. aspx?q=munk\%C3\%A1skamara+variet\%C3\%A9\&qhas=\&kw=\&fd=1993.01.01\&td=2006.11.14, Letöltés ideje: 2006. november 14 .

HVG (1994b): Párt-humánpolitika Ausztriában. Heti Világgazdaság. Letöltés helye: http://archivum.hvg.hu/Search. aspx?q=p\%C3\%A1rt-hum\%C3\%A1npolitika\&qhas=\&kw=\&fd=1993.01.01\&td=2006.11.14, Letöltés ideje: 2006. november 14

HVG (1994c): Osztrák választások. Új librettó. Heti Világgazdaság, 1994/40. Letöltés helye: http://archivum.hvg.hu/ Search.aspx?q=\%22osztr\%C3\%A1k+v\%C3\%A1laszt\%C3\%A1sok\%22\&qhas=\&kw=\&fd=1994.01.01\&td=2004.11.14, Letöltés ideje: 2006. november 14.

IMF (2003): Austria - Staff report. International Monetary Fund 03/372.

IMF (2005): Austria: Country Report. International Monetary Fund 05/248.

Körösi István (2004): Ausztria az Európai Unióban: érdekei a 2004. évi bővítésben. Magyar Tudományos Akadémia Világgazdasági Kutatóintézet, Mühelytanulmányok, 21-24.

Lehner, G. (2002): The Government Debt Committee and its recommendation in the 1990s. Letöltés helye: http://www. staatsschuldenausschuss.at/html/inhalt/download/pdf/recommendations_lehner.pdf, Letöltés ideje: 2006. május 31

Lengyel László (2006): Illeszkedés vagy kiválás. Budapest, Osiris, 251-286.

Nowotny, E. (1993): The Austrian Social Partnership and Democracy. Center for Austrian Studies, Working Paper, 93/1.

Oates, W. E. (1999): An essay on fiscal federalism. Journal of Economic Literature, Vol. 37, No. 3., 1120-1149.

OECD Statistical Database. Letöltés helye: http://www.oecd.int/olis, Letöltés ideje: 2006. május 29.

OECD (2003a): Assessment és recommendations. In: OECD Economic surveys Austria, 2003. 9-20.

OECD (2003b): Recent macroeconomic development and medium-term issues. In: OECD Economic Surveys Austria, $2003,21-42$.

OECD (2005a): Economic issues and policy challenges. In: OECD Economic Survey Austria, 2005. 23-39.

OECD (2005b): Executive summary. In: Economic Surveys Austria, 2005. 8-9.

OECD (2005c): Reforming federal fiscal relations. In: Economic Surveys Austria, 2005. 67-98.

OECD (2005d): Fiscal policy issues. In.: Economic Surveys Austria, 2005. 41-65.

Richter Sándor-Székffy Klára (1987): Ausztria gazdasága: Fejlődés, megtorpanás, válságjelenségek. Budapest, KJK, 1124.

Tanzi, V. (2000): On fiscal federalism: issues to worry about. In: Conference of fiscal decentralization, IMF. Letöltés helye: http://www.imf.org/external/pubs/ft/seminar/2000/fiscal/tanzi.pdf, Letöltés ideje: 2006. május 23.

Tálos, E. (2003): Szociális partnerség: demisztifikálás és alkalmazkodási kihívások között. In: Nyilas Mihály-Koncz János (szerk.): Ausztria szociálpolitikája. Budapest, Társadalompolitikai Olvasókönyvek, 285-308.

Tocqueville, A. de (1838): Democracy in America. Letöltés helye: http://xroads.virginia.edu/ HYPER/DETOC/1_ch08. htm, Letöltés ideje: 2006. május 22.

Von Hagen, J. (2003): Fiscal discipline and growth in euroland. Experiences with the stability and growth pact. ZEI Working Paper. Letöltés helye: http://www.zei.de/zei_english/f_search.htm, Letöltés ideje: 2006. augusztus 23.

Zöllner, E. (2000): Ausztria története. Budapest, Osiris, 416-424. 